\title{
MENCARI SOLUSI RENDAHNYA PEMBIAYAAN BAGI HASIL DI PERBANKAN SYARIAH INDONESIA
}

\author{
Ascarya \\ Diana Yumanita ${ }^{1}$
}

\begin{abstract}
A b stract
The lack of the profit and loss sharing (PLS) financing or the domination of the Non-PLS financing, especially murabahah, is a global phenomenon in Islamic banks everywhere. This paper analyses the problem in Indonesia using Analytic Network Process (ANP) methodology, preceeded with a focus group discussion (FGD) and an indepth interview with scholars and practitioners of Islamic banking to fully understand the problem and to develop an appropriate ANP network.

The cause of this problem can be grouped into four aspects, namely 1) internal of the Islamic bank; 2) customer; 3) regulation; and 4) government and other institutions. This research finds that the cause of the lack of PLS financing of Islamic banks in Indonesia can be summed up into two main causes from internal and regulation aspects, namely the lack of understanding and quality of human resource (Islamic bankers) and the lack of supportive regulations. The suggested solution is to increase the understanding and the quality of human resource by setting the minimum budget for training and education, implementing the insentive or subsidy system, setting the minimum standard for managers of Islamic banks through periodical fit and proper test, conducting training for short term needs, and encouraging the establishment of Islamic economic and banking education institutions for long term needs. Other suggested solution is to give support through regulation by reviewing the non supporting regulation, such as the collectibility classification of PLS financing, and developing incentive system to increase PLS financing. Moreover, the most effective policy strategy to overcome the problems of Islamic banks is by implementing directed market driven strategy, where policies are intended to direct the development of Islamic banks to stay on its syariah tracks towards the desired development goals.
\end{abstract}

JEL: C49, E58, G21, L22

Keywords: ANP, Bank Syariah, Islamic Bank, Bagi Hasil, Profit and Loss Sharing

1 Penulis adalah peneliti pada Pusat Pendidikan dan Studi Kebanksentralan Bank Indonesia, ascarya@bi.go.id 


\section{PENDAHULUAN}

\section{I.1 Latar Belakang}

Sejak berdirinya Bank Muamalat Indonesia tahun 1992, bank syariah mulai tumbuh dan berkembang di Indonesia. Secara perlahan bank syariah mampu memenuhi kebutuhan masyarakat yang menghendaki layanan jasa perbankan yang sesuai dengan prinsip syariah agama Islam yang dianutnya, khususnya yang berkaitan dengan pelarangan praktek riba, kegiatan yang bersifat spekulatif yang serupa dengan perjudian, ketidakjelasan, dan pelanggaran prinsip keadilan dalam bertransaksi, serta keharusan penyaluran pembiayaan dan investasi pada kegiatan usaha yang etis dan halal secara Syariah.

Perkembangan bank syariah yang pesat baru terasa semenjak Pemerintah dan Bank Indonesia memberikan komitmen besar dan menempuh berbagai kebijakan untuk mengembangkan bank syariah dengan serius, khususnya sejak perubahan UU perbankan dengan UU No. 10 tahun 1998. Berbagai kebijakan tersebut tidak hanya menyangkut perluasan jumlah kantor dan operasi bank-bank syariah untuk meningkatkan sisi penawaran, tetapi juga pengembangan pemahaman dan kesadaran masyarakat untuk meningkatkan sisi permintaan. Perkembangan yang pesat terutama tercatat sejak dikeluarkannya ketentuan Bank Indonesia yang memberi izin kepada bank konvensional untuk mendirikan suatu unit usaha syariah (UUS). Semenjak itu kantor dan operasi bank syariah tumbuh dimana-mana seperti jamur di musim hujan.

Dari pertumbuhan jumlah kantor, dua bank umum syariah (BUS) telah beroperasi di Indonesia dengan peningkatan dari 55 kantor pada akhir tahun 2000 menjadi 226 kantor sampai akhir Juni 2004. Sementara itu, tiga UUS yang memiliki 7 kantor pada akhir tahun 2000 telah tumbuh 91\% per tahun, dan sampai akhir Juni 2004 telah menjadi 10 UUS dengan 58 kantor. Selain itu, pangsa total aset perbankan syariah terhadap total aset seluruh perbankan yang baru 0,17\% pada akhir tahun 2000 telah tumbuh $65 \%$ per tahun, dan sampai akhir Juni 2004 telah menjadi 0,94\%. Sampai November 2004 telah bertambah lagi satu BUS, yaitu Bank Syariah Mega Indonesia, dan lima UUS, sehingga total kantor menjadi 322 buah, dan pangsa total asset $1.1 \%$.

Perkembangan yang pesat juga dapat dilihat pada mobilisasi dan penyaluran dana perbankan syariah. Dari sisi simpanan masyarakat, dana pihak ketiga yang pada akhir tahun 2000 berjumlah Rp.1,03 trilliun telah tumbuh 77,76\% per tahun, dan pada akhir Juni 2004 telah menjadi Rp.8.48 triliun. Dari sisi penyaluran dana atau pembiayaan yang diberikan yang pada akhir tahun 2000 berjumlah Rp.1,27 trilliun telah tumbuh 63,29\% per tahun, dan pada akhir Juni 2004 telah menjadi Rp.8.42 triliun. Lebih dari itu, perbankan syariah di Indonesia 
juga mempunyai prestasi yang tidak dimiliki oleh perbankan syariah dimanapun di dunia dengan angka FDR (financing to deposit ratio) yang rata-rata sebesar 99.32\% pada akhir Juni 2003. Angka ini jauh di atas LDR (Ioan to deposit ratio) perbankan konvensional di Indonesia yang hanya sebesar 53.1\% pada akhir Juni 2003.

Namun demikian, jika dilihat lebih jauh lagi, khususnya terkait dengan komposisi pembiayaan di bank syariah, maka tampak bahwa komposisi pembiayaan di bank syariah pada akhir tahun 2003 terdiri dari pembiayaan musyarakah sebesar 5,53\%, pembiayaan mudharabah sebesar $14,36 \%$, pembiayaan murabahah sebesar 71,53\%, dan pembiayaan lainnya sebesar $12,01 \%$. Komposisi ini menunjukkan bahwa dominasi pembiayaan nonbagi hasil, terutama murabahah, masih sangat besar yaitu 80,11\%. Sementara itu, pembiayaan bagi hasil, mudharabah dan musyarakah, hanya sebesar 19,89\%. Padahal pola pembiayaan bagi hasil, selain merupakan esensi pembiayaan syariah, juga lebih cocok untuk menggiatkan sektor riil, karena meningkatkan hubungan langsung dan pembagian risiko antara investor dengan pengusaha.

Sebagian besar ulama dan pakar juga sependapat bahwa bank syariah merupakan bank yang berprinsip utama bagi hasil, sehingga pembiayaan bagi hasil seharusnya lebih diutamakan dan dominan dibandingkan dengan pembiayaan nonbagi hasil. Sementara sebagian pakar yang lain memandang wajar kecenderungan pembiayaan nonbagi hasil bank syariah, khususnya pada tahap awal pengembangan mengingat berbagai kendala yang dihadapi.

Terlepas dari perdebatan tersebut, fenomena rendahnya pembiayaan bagi hasil merupakan permasalahan penting yang perlu di bahas. Berbagai permasalahan dan solusi yang tepat perlu dicari untuk meningkatkan pembiayaan bagi hasil perbankan syariah. Terlebih lagi, rendahnya pembiayaan bagi hasil cenderung merupakan masalah yang multi dimensi yang telah terjadi sejak lama dan tidak ada kecenderungan untuk berubah. Implikasi dari tingginya pembiayaan nonbagi hasil ini adalah terbentuknya persepsi publik bahwa perbankan syariah hampir tidak ada bedanya dengan perbankan konvensional. Persepsi yang demikian akan membentuk suatu risiko reputasi tersendiri yang dikhawatirkan akan menimbulkan sinisme dikalangan masyarakat bahwa bisnis perbankan syariah hanya merupakan pergantian nama saja sedangkan 'mindset' pelakunya tetaplah konvensional. Permasalahan menjadi semakin penting karena kondisi yang demikian juga terjadi di negara-negara yang menerapkan sistem perbankan syariah, terutama di negara-negara yang menerapkan dual banking system, seperti di Mesir, Bangladesh, dan Malaysia.

Rendahnya pembiayaan bagi hasil jelas bukanlah kondisi ideal yang diinginkan. Industri perbankan syariah bersama-sama dengan pemerintah maupun Bank Indonesia harus terus 
mempersiapkan sistem maupun infrastruktur dengan mencari solusi yang tepat untuk meningkatkan pembiayaan bagi hasil. Persiapan itu jelas tidak dapat dilakukan secara mendadak, melainkan mau tidak mau harus mulai dipersiapkan dari sekarang, karena perkembangan pesat yang sedang berlangsung perlu diarahkan agar tidak terlanjur berkembang ke arah yang tidak diinginkan.

\section{I.2 Maksud dan Tujuan Penelitian}

Penelitian ini dimaksudkan untuk mengidentifikasi fakor-faktor yang mempengaruhi rendahnya pembiayaan bagi hasil di perbankan Syariah Indonesia, kemudian untuk dapat dipakai sebagai landasan dalam memberikan berbagai alternatif pemecahan dan strategi kebijakan yang tepat untuk mengatasi masalah tersebut. Kemudian, untuk memberikan masukan kepada stakeholder terkait seperti, industri perbankan syariah, nasabah peminjam, Bank Indonesia, maupun pemerintah untuk dapat mengambil policy action yang tepat untuk mengatasi masalahmasalah yang ada, dalam rangka mencapai tujuan yang diinginkan.

\section{I.3 Metodologi}

Untuk sampai kepada tujuan penelitian yang diinginkan, beberapa tahapan dilakukan. Focus Group Discussion (FGD) dan indepth interview dilakukan untuk mendapatkan gambaran mendalam mengenai masalah rendahnya pembiayaan bagi hasil ini. Hasilnya kemudian dipergunakan sebagai dasar merancang model dalam kerangka metode Analytic Network Process (ANP) beserta model kuesionernya untuk mendapatkan data yang diperlukan. Setelah itu, survey menggunakan kuesioner ini dilakukan kepada pakar dan perbankan yang dianggap paling menguasai dan ahli tentang masalah ini. ANP kemudian digunakan untuk mencari prioritas alternatif solusi dan strategi kebijakan yang tepat, sehingga dapat memberikan masukan policy recommendations yang tepat dan optimal.

\section{LANDASAN TEORI}

\section{II.1 Gambaran Umum ANP}

Analytic Network Process atau ANP adalah teori umum pengukuran relatif yang digunakan untuk menurunkan rasio prioritas komposit dari skala rasio individu yang mencerminkan pengukuran relatif dari pengaruh elemen-elemen yang saling berinteraksi berkenaan dengan kriteria kontrol (Saaty, 1999). ANP merupakan teori matematika yang memungkinkan seseorang 
untuk memperlakukan dependence dan feedback secara sistematis yang dapat menangkap dan mengkombinasi faktor-faktor tangible dan intangible (Azis, 2003). ANP merupakan pendekatan baru dalam proses pengambilan keputusan yang memberikan kerangka kerja umum dalam memperlakukan keputusan-keputusan tanpa membuat asumsi-asumsi tentang independensi elemen-elemen pada level yang lebih tinggi dari elemen-elemen pada level yang lebih rendah dan tentang independensi elemen-elemen dalam suatu level. Malahan ANP menggunakan jaringan tanpa harus menetapkan level seperti pada hierarki yang digunakan dalam Analytic Hierarchy Process (AHP), yang merupakan titik awal ANP. Konsep utama dalam ANP adalah influence 'pengaruh', sementara konsep utama dalam AHP adalah preferrence 'preferensi'. AHP dengan asumsi-asumsi dependensinya tentang cluster dan elemen merupakan kasus khusus ANP.

Pada jaringan AHP terdapat level tujuan, kriteria, subkriteria, dan alternatif, dimana masingmasing level memiliki elemen. Sementara itu, pada jaringan ANP, level dalam AHP disebut cluster yang dapat memiliki kriteria dan alternatif di dalamnya, yang sekarang disebut simpul (baca gambar II.1).

Dengan feedback, alternatif-alternatif dapat bergantung/terikat pada kriteria seperti pada hierarki tetapi dapat juga bergantung/terikat pada sesama alternatif. Lebih jauh lagi, kriteriakriteria itu sendiri dapat tergantung pada alternatif-alternatif dan pada sesama kriteria (baca gambar II.1). Sementara itu, feedback meningkatkan prioritas yang diturunkan dari judgements dan membuat prediksi menjadi lebih akurat. Oleh karena itu, hasil dari ANP diperkirakan akan lebih stabil. Dari jaringan feedback pada gambar II. 1 dapat dilihat bahwa simpul atau elemen utama dan simpul-simpul yang akan dibandingkan dapat berada pada cluster-cluster yang berbeda. Sebagai contoh, ada hubungan langsung dari simpul utama $C_{4}$ ke cluster lain $\left(C_{2}\right.$ dan $\mathrm{C}_{3}$ ), yang merupakan outer dependence. Sementara itu, ada simpul utama dan simpul-simpul yang akan dibandingkan berada pada cluster yang sama, sehingga cluster ini terhubung dengan dirinya sendiri dan membentuk hubungan loop. Hal ini disebut inner dependence.

Dalam suatu jaringan, elemen dalam suatu komponen/cluster bisa saja berupa orang (contoh, individu di Bank Indonesia) dan elemen dalam komponen/cluster yang lain bisa saja juga berupa orang (contoh, individu di DPR). Elemen dalam suatu komponen/cluster dapat mempengaruhi elemen lain dalam komponen/cluster yang sama (inner dependence), dan dapat pula mempengaruhi elemen pada komponen/cluster yang lain (outer dependence) dengan memperhatikan setiap kriteria. Yang diinginkan dalam ANP adalah mengetahui keseluruhan pengaruh dari semua elemen. Oleh karena itu, semua kriteria harus diatur dan dibuat prioritas dalam suatu kerangka kerja hierarki kontrol atau jaringan, melakukan perbandingan dan sintesis untuk memperoleh urutan prioritas dari sekumpulan kriteria ini. Kemudian kita turunkan 
pengaruh dari elemen dalam sistem feedback dengan memperhatikan masing-masing kriteria. Akhirnya, hasil dari pengaruh ini dibobot dengan tingkat kepentingan dari kriteria, dan ditambahkan untuk memperoleh pengaruh keseluruhan dari masing-masing elemen.

\section{Hierarki Linier}

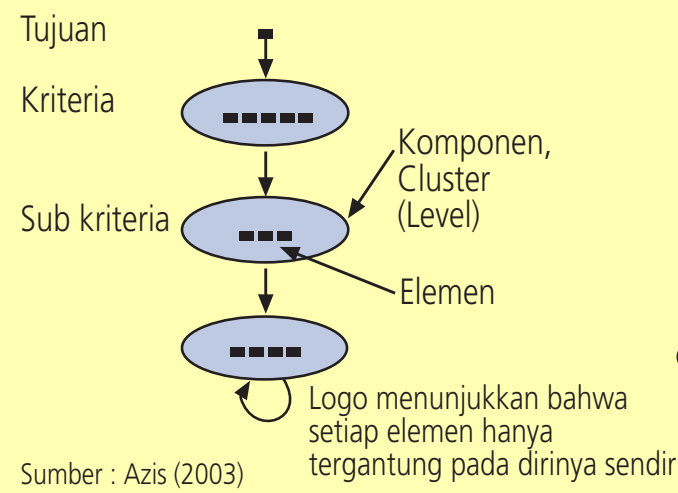

\section{Jaringan Feedback}

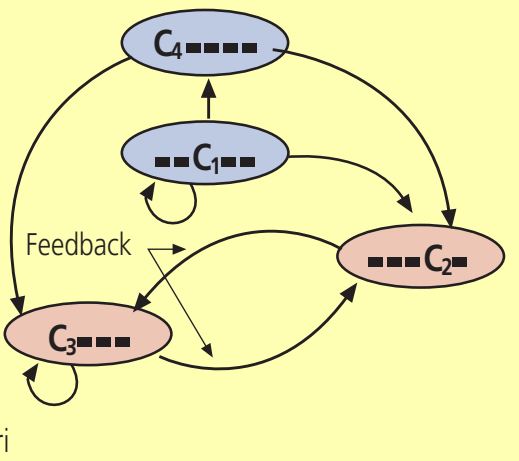

Gambar II.1 Perbedaan Hierarki dan Jaringan

Tujuh pilar AHP dapat dijadikan titik awal dari ANP2. ANP merupakan gabungan dari dua bagian. Bagian pertama terdiri dari hierarki kontrol atau jaringan dari kriteria dan subkriteria yang mengontrol interaksi. Bagian kedua adalah jaringan pengaruh-pengaruh diantara elemen dan cluster.

AHP dan ANP sama-sama menggunakan skala rasio. Prioritas-prioritas dalam skala rasio merupakan angka fundamental yang memungkinkan untuk dilakukannya perhitungan operasi aritmatika dasar seperti penambahan dan pengurangan dalam skala yang sama, perkalian dan pembagian dari skala yang berbeda, dan mengkombinasikan keduanya dengan pembobotan yang sesuai dan menambahkan skala yang berbeda untuk memperoleh skala satu dimensi. Perlu diingat bahwa skala rasio juga merupakan skala absolut. Kedua skala tersebut diperoleh dari pairwise comparison 'pembandingan sepasang-sepasang' dengan menggunakan judgements atau rasio dominasi pasangan dengan menggunakan pengukuran aktual. Dalam hal penggunaan judgements, dalam AHP seseorang bertanya: "Mana yang lebih disukai atau lebih penting?", sementara dalam ANP seseorang bertanya: "Mana yang mempunyai pengaruh lebih besar?" Pertanyaan terakhir jelas memerlukan observasi faktual dan pengetahuan untuk menghasilkan jawaban-jawaban yang valid, yang membuat pertanyaan kedua lebih obyektif 
dari pada pertanyaan pertama. Prosedur untuk mendapatkan skala rasio dapat dibaca pada lampiran II.1, sedangkan supermatriks dalam ANP dapat dibaca pada lampiran II.2.

\section{KARAKTERISTIK BANK SYARIAH DI BEBERAPA NEGARA}

Untuk dapat melihat permasalahan rendahnya pembiayaan bagi hasil di perbankan syariah Indonesia dengan lebih obyektif dan komprehensif, perlu dilakukan perbandingan dengan negara lain yang juga menerapkan sistem perbankan syariah, untuk melihat kondisi perbankan Syariah serta praktek perbankan Syariah yang dijalankan di negara lain, masalah rendahnya pembiayan bagi hasil, dan alternatif solusi/kebijakan yang mereka terapkan. Beberapa negara tersebut antara lain Sudan yang menerapkan sistem ekonomi Islam penuh dan Malaysia yang menerapkan dual banking system seperti di Indonesia.

\section{III.1 Sudan}

Sudan merupakan salah satu negara yang menerapkan sistem ekonomi Islam secara penuh, dimana seluruh sistem keuangannya menerapkan prinsip-prinsip syariah di dalam operasionalnya. Sistem perbankan merupakan sistem yang pertama kali diterapkan secara islami pada tahun 1984, baru kemudian diterapkan sistem keuangan secara islami penuh pada tahun 1992.

Dengan jumlah penduduk yang mencapai 38 juta jiwa, luas wilayah yang mencapai 2,5 juta km persegi (1,25 kali luas Indonesia), dan jumlah penduduk muslim yang mencapai $70 \%$, jumlah bank disana hanya sebanyak 26 bank. Artinya paling tidak satu bank menangani 1,02 juta penduduk. Jumlah tersebut relatif lebih rendah jika dibandingkan dengan perbankan di Indonesia, paling tidak dengan jumlah penduduk muslim sebesar 206 juta penduduk dengan jumlah bank syariah sebanyak 14 (3 BUS dan 11 UUS), satu bank menangani sebesar 14,7 juta penduduk.

\section{III.1.1 Peran Bank of Sudan}

Bank of Sudan memiliki peranan yang sangat besar di dalam perkembangan perbankan syariah di Sudan. Dalam hal ini BOS memiliki komitmen yang kuat untuk mengembangkan perbankan Islam yang benar-benar sesuai dengan Syariah. Hal ini terlihat pada kebijakan atau regulasi yang dikeluarkan oleh BOS dalam rangka mendorong pertumbuhan pembiayaan musyarakah dan mudharabah. 
Sejak awal berdirinya perbankan syariah di Sudan, pada umumnya skim pembiayaan lebih banyak menggunakan murabahah. Dengan latar belakang demikian, pada tahun 2000 BOS mengeluarkan kebijakan kredit dalam rangka menekan pertumbuhan skim murabahah. Kebijakan kredit yang dikeluarkan cenderung memberikan disinsentif kepada perbankan dalam praktek pembiayaan murabahah, yaitu dengan mematok komposisi pembiayaan murabahah sebesar 30\% dari total pembiayaan bank. Disamping itu, bank sentral juga mematok besarnya margin yang dapat diambil bank dalam skim murabahah paling tinggi sebesar 10\% (disesuaikan dengan tingkat inflasi). Namun, demikian semua kebijakan tersebut tidak mengikat, artinya tidak ada sanksi kepada bank jika tidak mencapai komposisi tersebut.

Ketentuan lain yang mendorong pembiayaan bagi hasil adalah ketentuan perhitungan ATMR pembiayaan mudharabah dan musyarakah sebesar $100 \%$ yang sama dengan perhitungan ATMR kredit pada bank konvensional. Disamping itu, perhitungan kolektabilitas pembiayaan mudharabah dan musyarakah lebih ringan dibandingkan dengan perhitungan kolektabilitas pembiayaan murabahah:

- Pembiayaan mudharabah dan musyarakah diklasifikasikan lancar sampai dengan tiga bulan setelah jangka waktu berakhir, tanpa melihat kondisi pembiayaan maupun bagi hasil yang diberikan (untung/rugi). Pembiayaan mudharabah dan musyarakah diklasifikasikan non performing (kurang lancar) apabila telah melebihi tiga bulan setelah jangka waktu berakhir namun belum dilunasi.

- Pembiayaan murabahah sudah dapat diklasifikasikan sebagai non performing (kurang lancar) apabila terdapat tunggakan yang melebihi satu bulan.

\section{III.1.2 Komposisi Pembiayaan}

Dilihat dari komposisi pembiayaan mudharabah dan musyarakah di Sudan, meskipun kebijakan untuk menghambat penyaluran pembiayaan kepada skim murabahah, tampak bahwa lonjakan skim pembiayaan yang lain tidak terlalu signifikan. Menurut Dr. Ahmed Ali Abdalah pencapaian komposisi tersebut masih jauh dari yang diharapkan. Menurut Dr. Ahmed, ada bank yang sukses dalam menyalurkan pembiayaan mudharabah dan musyarakah tetapi ada juga bank yang tidak sukses melakukannya. Bank yang umumnya tidak sukses dalam pembiayaan tersebut berasal dari bank-bank konvensional, karena ketentuan beralih kepada bank syariah. Artinya sumber daya yang tersedia tidak siap atau belum cukup memiliki pengalaman dengan bentuk-bentuk pembiayaan bank syariah, dan cenderung bersikap layaknya conventional bankers. Disamping itu, kalangan perbankan juga memiliki orientasi bisnis yang tinggi serta tidak memiliki mental yang kuat untuk mengambil risiko menyebabkan bank-bank tersebut cenderung membiayai skim murabahah. 
Sedangkan bank-bank yang sukses, artinya yang komposisi skim pembiayaan bagi hasilnya cukup tinggi, lebih banyak dimiliki oleh bank-bank yang pada awal berdirinya sudah menggunakan sistem syariah. Sumber daya insani di bank-bank ini lebih siap menghadapi risiko karena memiliki pengalaman yang lebih banyak dibandingkan dengan bank-bank yang sebelumnya berbasiskan konvensional.

\begin{tabular}{|c|c|c|c|c|c|}
\hline \multicolumn{6}{|c|}{$\begin{array}{c}\text { Tabel II.1 } \\
\text { Perkembangan Komposisi Pembiayaan di Sudan }\end{array}$} \\
\hline & 1999 & 2000 & 2001 & 2002 & 2003 \\
\hline Mudharabah & $9,8 \%$ & $1,7 \%$ & $4,8 \%$ & $2,5 \%$ & $6,9 \%$ \\
\hline Musharakah & $29,3 \%$ & $52,0 \%$ & $26,9 \%$ & $25,8 \%$ & $23,4 \%$ \\
\hline Murabahah & $45,1 \%$ & $29,1 \%$ & $38,0 \%$ & $30,0 \%$ & $36,7 \%$ \\
\hline Others & $13,4 \%$ & $14,7 \%$ & $25,5 \%$ & $37,5 \%$ & $33 \%$ \\
\hline
\end{tabular}

Pada tabel II.1 tampak bahwa skim musyarakah lebih diminati dibandingkan dengan skim mudharabah. Hal ini disebabkan oleh:

a. Skim mudharabah dinilai lebih berisiko karena 100\% dana berasal dari bank. Tidak adanya partisipasi nasabah didalam pembiayaan tersebut akan menyebabkan risiko ketidakhatihatian dari nasabah akan semakin tinggi.

b. Kultur masyarakat Sudan yang cenderung lebih senang mencari pembiayaan dibandingkan dengan menyimpan dana. Dengan musyarakah dimaksudkan agar nasabah berpartisipasi juga dalam hal keuangan, sehingga diharapkan akan tercipta dorongan untuk menabung pada masyarakat Sudan.

Dengan komposisi yang demikian, bahwa porsi pembiayaan bagi hasil dan non bagi hasil relatif seimbang, tingkat non performing financing (NPF) secara keseluruhan hanya 2,5\%. Keberhasilan ini terkait dengan kemampuan bank dalam memilih nasabah dan proyek yang akan dibiayai. Adapun langkah-langkah yang diambil oleh bank dalam menyalurkan pembiayaan mudharabah dan musyarakah adalah:

- Melakukan evaluasi terhadap karakter nasabah, bahwa nasabah harus jujur dan memiliki akhlak yang baik. Umumnya, bank meminta nasabah memiliki record di bank tersebut paling tidak dua tahun, atau nasabah memiliki personal guarantee dari pihak lain. Apabila nasabah merupakan nasabah baru, akan diuji dulu dengan jumlah pembiayaan yang kecil, baru bertahap akan meningkat;

- Melakukan evaluasi terhadap nasabah dan proyek sebelum penyaluran pembiayaan, termasuk meminta feasibility study. Karakter nasabah pembiayaan harus dapat dipercaya, 
memiliki track record baik, dan memiliki pengalaman minimum tiga tahun atas proyek yang akan dibiayai. Proyek harus profitable, dengan commodity yang tidak musiman serta memiliki banyak pasar/pembeli;

- Penyaluran pembiayaan hanya disalurkan pada proyek-proyek yang telah dikuasai oleh bank, untuk menghidari kecurangan yang dilakukan oleh nasabah;

- Melakukan montoring secara berkala terhadap pembiayaan yang telah disalurkan, termasuk melakukan analisis terhadap laporan keuangan nasabah;

- Membuat rekening khusus bagi setiap pembiayaan yang disalurkan untuk menampung transaksi yang dilakukan nasabah untuk sarana monitoring;

- Meminta collateral, bila diperlukan, untuk mengurangi moral hazard dari nasabah. Eksekusi collatera/ dilakukan apabila ditemukan kecurangan atau salah penggunaan oleh nasabah;

- Untuk pembiayaan musyarakah, minimum share capitalyang harus dipenuhi nasabah sebesar $20 \%$; dan

- Umumnya barang atau komoditi yang dibiayai bukan barang musiman atau sedikit permintaannya, dan juga bukan barang monopoli.

\section{III.2 Malaysia}

Malaysia merupakan salah satu negara yang menjadi pelopor berdirinya bank yang berbasiskan Islam di Asia Tenggara ini. Tidak berbeda dengan di Indonesia, penduduk Muslim Malaysia pun hanya memanfaatkan jasa bank konvensional sebelum berdirinya bank yang berbasiskan syariah. Sebagai negara yang mayoritas penduduknya adalah Muslim, dorongan untuk mendirikan bank yang berbasiskan Islam pun sangat kuat. Sebagai contoh, pada tahun 1980 The Bumiputera Economic Congress mendesak pemerintah untuk mendirikan bank Islam di negara tersebut. Usaha lain seperti yang dilakukan oleh National Steering Committee pada tahun 1981 membuat suatu kajian dan rekomendasi kepada pemerintah tentang semua aspek pendirian maupun operasional bank Islam, termasuk masalah hukum, aspek religius, dan aspek operasional kepada pemerintah. Semenjak itu berdirilah Bank Islam pertama di Malaysia yaitu "Bank Islam Malaysia Berhad" pada bulan Juli tahun 1983.

Tidak berbeda dengan Indonesia, sistem perbankan yang dianut oleh perbankan Malaysia juga menggunakan dual banking system. Sehingga, pertumbuhan perbankan Islam sejak berdirinya hingga sekarang tidak terlalu menunjukkan peningkatan yang cukup besar. Namun, pangsa perbankan syariah di Malaysia terhadap perbankan nasional masih lebih tinggi daripada pangsa perbankan syariah di Indonesia, yaitu sebesar 9.7\%, sedangkan Indonesia masih sekitar $1 \%$. Bahkan didalam financial framework-nya BNM mentargetkan pangsa perbankan syariah sebesar 20\% tahun 2010. 
Pada dasarnya lembaga keuangan yang berbasiskan Islam sudah berdiri di Malaysia sejak tahun 1963 yang bernama "Lembaga Tabung Haji". Lembaga keuangan ini dimaksudkan untuk menutupi biaya perjalanan ibadah haji kaum Muslim di Malaysia. Namun, dana tersebut di gunakan untuk membiayai kembali sektor-sektor yang produktif dengan tujuan untuk menghindari riba.

Pemerintah juga memegang peranan yang cukup penting di dalam perkembangan bank syariah di kemudian harinya. Salah satu usaha pemerintah untuk mendorong perkembangan bank syariah adalah dengan mengeluarkan kebijakan yang disebut "Skim Perbankan Islam" (SPI) pada bulam Maret 1993. SPI memberikan izin kepada bank-bank konvensional maupun lembaga keuangan konvensional lainnya untuk menawarkan produk-produk atau jasa-jasa yang berasaskan syariah dengan menggunakan sarana infrastruktur termasuk karyawan maupun cabang-cabang yang sudah ada. Dengan dikeluarkannya SPI jumlah bank syariah berkembang dengan pesat, dari hanya tiga bank pada tahun 1993, jumlah lembaga keuangan syariah meningkat hingga mencapai 36 buah. Dan pada tahun 1999, Bank Islam yang kedua berdiri yaitu "Bank Muamalat Malaysia Berhad."

\section{III.2.1 Peran Bank Negara Malaysia}

Berbeda dengan Bank of Sudan dimana bank sentral cenderung memberikan kebijakan yang mengarahkan pasar, Bank Negara Malaysia cenderung mengikuti keinginan pasar. Sehingga bank sentral belum memasukkan target mudharabah dan musyarakah, karena dilihat dari permintaan belum tinggi.

Peran bank sentral yang paling besar di dalam bank syariah adalah bahwa setiap produk yang dikeluarkan oleh perbankan syariah harus mendapatkan persetujuan dari Bank Negara Malaysia. Sampai dengan saat ini jumlah produk perbankan syariah yang telah disetujui oleh Bank Negara Malaysia mencapai 58 produk. Persetujuan produk ini tidak akan bertentangan dengan fatwa karena kedudukan dewan syariah nasional berada di dalam bank sentral.

\section{III.2.2 Komposisi Pembiayaan}

Sejak berdirinya bank syariah yang pertama, komposisi pembiayaan cenderung tidak berubah, lebih banyak kepada pembiayaan murabahah. Saat ini (posisi Juni 2004) total pembiayaan perbankan syariah mencapai $11 \%$ dari total pembiayaan perbankan seluruhnya. Sedangkan komposisi pembiayaan mudharabah dan musyarakah hanya sebesar $0.5 \%$, masih lebih rendah dari Indonesia. Skim pembiayaan murabahah dan Bai Bithaman Ajil lebih mendominasi. 


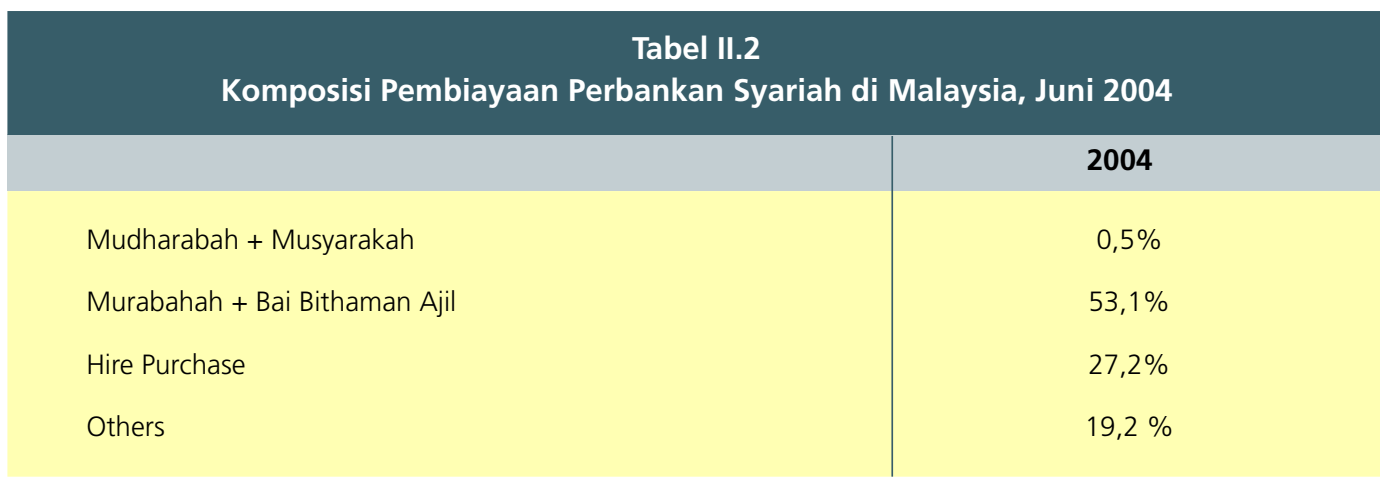

Hal yang membedakan perkembangan bank Islam di Indonesia dengan Malaysia adalah produk pasar modal Sukuk. Sukuk ini sudah banyak digunakan oleh perbankan syariah di Malaysia. Sedangkan di Indonesia penggunaan sukuk sebagai suatu instrumen keuangan syariah masih diperdebatkan dan baru sedikit dipergunakan.

Dilihat dari regulasi bank sentralnya, belum ada kebijakan yang mendorong peningkatan skim pembiayaan bagi hasil. Dalam hal ini, bank sentral cenderung melihat permintaan pasar (market driven). Beberapa faktor yang menyebabkan rendahnya pembiayaan bagi hasil ini, menurut BNM, antara lain :

a. Umumnya masih terpengaruh oleh paradigma konvensional, biaya monitoring yang tinggi dan cenderung memiliki profit yang lebih rendah;

b. Cenderung tidak mau mengambil risiko dengan kondisi asymmetric information;

c. Risiko dan moral hazard yang lebih tinggi didalam praktek pembiayaan bagi hasil;

d. Permintaan terhadap skim pembiayaan ini juga sedikit, karena debitur cenderung memilih pembiayaan dengan bunga sehingga bisa mengatur cash flow-nya;

e. Perusahaan cenderung tidak ingin melakukan join management atau pembagian keuntungan terutama untuk proyek-proyek yang sangat menguntungkan.

Selain itu, Samad dan Hassan (1999) menambahkan kurangnya SDI (Islamic bankers) yang memiliki pengetahuan cukup, khususnya dalam:

1. Menyeleksi proyek bagi hasil yang menguntungkan;

2. Mengelola proyek bagi hasil; dan

3. Mengeavaluasi tingkat keuntungan dari suatu proyek;

\section{III.3 Negara Lain}

Selain Sudan dan Malaysia banyak negara lain di timur maupun di barat yang memiliki bank syariah. Negara lain yang menerapkan fully islamic banking/financial system adalah Pakistan, 
Iran, dan Irak. Negara lain yang menerapkan dual banking system adalah Mesir, Bangladesh, Uni Emirat Arab, Kuwait, dan lain-lain.

Mesir merupakan negara yang pertama kali mencoba mendirikan bank syariah Mit Ghamr pada tahun 1963. Di Bangladesh, bank syariah muncul pertama kali pada tahun 1983 dengan berdirinya Islamic Bank Bangladesh Limited (IBBL). Sampai sekarang sudah terdapat lima BUS dan dua UUS.

Sementara itu, Pakistan menghapus bunga dari sistem perekonomian secara bertahap pada periode 1980-1985 dengan komitmen penuh pemerintah. Strategi yang diterapkan adalah dengan mendirikan BUS di sektor swasta dan bank komersial diijinkan mendirikan cabang bank dan kantor kas syariah. Salah satu BUS yang besar adalah AI Baraka Islamic Bank yang memiliki komposisi bagi hasil hanya $2 \%$.

Secara umum perbankan syariah di manapun memiliki masalah rendahnya pembiayaan bagi hasil, baik yang menerapkan fully islamic financial system atau yang menerapkan dual banking system. Dari sekian banyak negara yang memiliki bank syariah, hanya Sudan saja yang mempunyai success story dalam meningkatkan pembiayaan bagi hasil di perbankan syariahnya.

\section{III.4 Indonesia}

Perkembangan perbankan syraiah di Indonesia dapat dibagi menjadi dua fase, yaitu fase sebelum tahun 1998 dan fase setelah tahun 1998. Fase pertama ini diawali dengan berdirinya Bank Muamalat pada tahun 1992, namun jauh sebelum berdirinya Bank Muamalat konsep perbankan syariah ini sudah merupakan bahawan diskusi ulama, cendikiawan Islam pada awal tahun 1980-an. Bahkan saat itu juga dilakukan uji coba terhadap bentuk lembaga keuangan yang berdasarkan prinsip bagi hasil yaitu Baitul Tamwil Salman Bandung dan kopoerasi Ridho Gusti di Jakarta. Wacana lembaga keuangan seperti ini diangkat kembali pada lokakarya dan munas MUI tahun 1990, bahkan para ulama sepakat untuk mendorong pemerintah agar terwujud suatu lembaga keuangan khususnya perbankan yang berlandaskan prinsip bagi hasil. Pada akhirnya pemerintah mulai mengakomodasi keinginan ini untuk memberikan kesempatan kepada bank untuk melakukan usaha dengan sistem bagi hasil yang tertuang didalam UU perbankan No. 7 tahun 1992.

Fase kedua adalah fase setelah dikeluarkannya undang-undang No 10 tahun 1998, dimana pemerintah semakin menunjukkan komitmennya kepada perbankan syariah dengan memberikan landasan hukum yang kuat dengan mengizinkan perbankan konvensional untuk 
membuka unit usaha syraiah. Kebijakan ini tentu saja membuka jalan bagi perkembangan perbankan syariah, karena sejak Bank Muamalat didirkan pada tahun 1992, tidak ada lagi bank syariah yang berdiri. Namun, sejak dikelaurkannya undang-undang tersebut beberapa bank konvensional mulai membuka unit-unit usaha syariahnya. Maraknya unit-unit usaha syariah yang dibuka pasca UU tersebut juga didorong oleh kenyataan bahwa bank syariah terbukti tidak mengalami goncangan yang signifikan pada saat terjadi krisis pada pertengahan tahun 1997.

Pada tahap-tahap selanjutnya pemerintah maupun Bank Indonesia semakin menunjukkan komitmennya untuk mengembangkan perbankan syariah. Dalam UU No. 23 tahun 1999, dikemukakan bahwa Bank Indonesia bertanggung jawab untuk mengatur dan mengawasi bank, termasuk bank umum syariah dan BPRS, BI berwenang untuk melakukan pengawasan moneter berdasarkan prinsip syariah, dan seiring dengan kebijakan tersebut pula tim peneliti BI untuk perbankan syariah dibentuk. Pada tahun yang sama bank syraiah kedua juga dibuka yaitu Bank Syariah Mandiri, sebelumnya merupakan bank konvensional yaitu Bank Susila Bakti yang dikonversi menjadi bank syariah. Sejak itu, perbankan syariah berkembang dengan pesat. Bank Syariah Mandiri merupakan bank yang paling cepat ekspansinya, saat ini pun kantor cabanga BSM sudah menyebar hampir di seluruh propinsi di Indonesia.

Jika dibandingkan dengan perkembangan jumlah bank maupun jumlah kantor cabang bank syariah, perkembangan perbankan di Indonesia jauh lebih cepat dibandingkan dengan Malaysia. Dalam jangka waktu 12 tahun, jumlah perbankan syariah di Indonesia sudah mencapai dua BUS dengan 231 kantor bank, dan 10 UUS dengan 58 kantor bank (data per Juni 2004).

\section{III.4.1 Peran Bank Indonesia}

Bank Indonesia memiliki peran yang besar dalam perkembangan perbankan syariah di Indonesia sejak diberi amanah dalam pengaturan perbankan dan moneter syariah yang tertuang dalam UU No. 23 Tahun 1999. Sejak itu BI membentuk Tim Peneliti untuk perbankan syariah yang pada tahun 2001 menjadi unit kerja setingkat biro (Biro Perbankan Syariah), dan kemudian menjadi Direktorat Perbankan Syariah pada akhir tahun 2003.

Strategi BI dalam pengembangan perbankan syariah lebih bersifat market driven, seperti yang tertuang dalam blue print. Namun demikian, Bl juga mempunyai target-target yang ingin dicapai sampai tahun 2011 dalam tiga tahapan. Salah satunya adalah target meningkatkan proporsi pembiayaan bagi hasil pada tahun 2008-2011. Usaha-usaha kearah 
itu secara tidak langsung mulai dilakukan dengan memberikan pelatihan pemberian pembiayaan bagi hasil bagi AO perbankan syariah, melakukan standarisasi akad-akad pembiayaan dalam rangka pemurnian operasi bank syariah, melakukan sosialisai perbankan syariah kepada masyarakat, melakukan penelitian terkait, mengadakan seminar nasional maupun internasional, dan lain sebagainya.

\section{III.4.2 Komposisi Pembiayaan}

Porsi pembiayaan bagi hasil sejak tahun 2000 menunjukkan kecenderungan yang terus menurun dan baru mulai meningkat lagi di tahun 2003. Sementara itu porsi murabahah menunjukkan kecenderungan yang terus meningkat. Porsi pembiayaan bagi hasil yang sekitar 20\% dan nonbagi hasil 80\% ini masih lebih baik dari Malaysia, namun belum sebaik di Sudan. Pangsa pembiayaan bank syariah yang baru mencapai 1,64\% dari total perbankan nasional (per Juni 2004) masih jauh jika dibandingkan dengan Malaysia.

\begin{tabular}{|c|c|c|c|c|}
\hline \multicolumn{5}{|c|}{$\begin{array}{l}\text { Tabel II.3 } \\
\text { mposisi Pembiayaan di Indonesia }\end{array}$} \\
\hline & 2000 & 2001 & 2002 & 2003 \\
\hline Mudharabah & $29,8 \%$ & $19,6 \%$ & $15,2 \%$ & $14,4 \%$ \\
\hline Musharakah & $2,5 \%$ & $2,6 \%$ & $1,8 \%$ & $5,5 \%$ \\
\hline Murabahah & $61,0 \%$ & $69,3 \%$ & $70,9 \%$ & $71,5 \%$ \\
\hline Others & $6,7 \%$ & $8,5 \%$ & $12,1 \%$ & $8,6 \%$ \\
\hline
\end{tabular}

Tabel II.4 memperlihatkan perbandingan secara umum keadaan perbankan syariah di Indonesia, Malaysia, dan Sudan. 
Tabel II.4

Tabel Perbandingan Antara Indonesia, Malaysia dan Sudan

\section{Hasil Studi Banding}

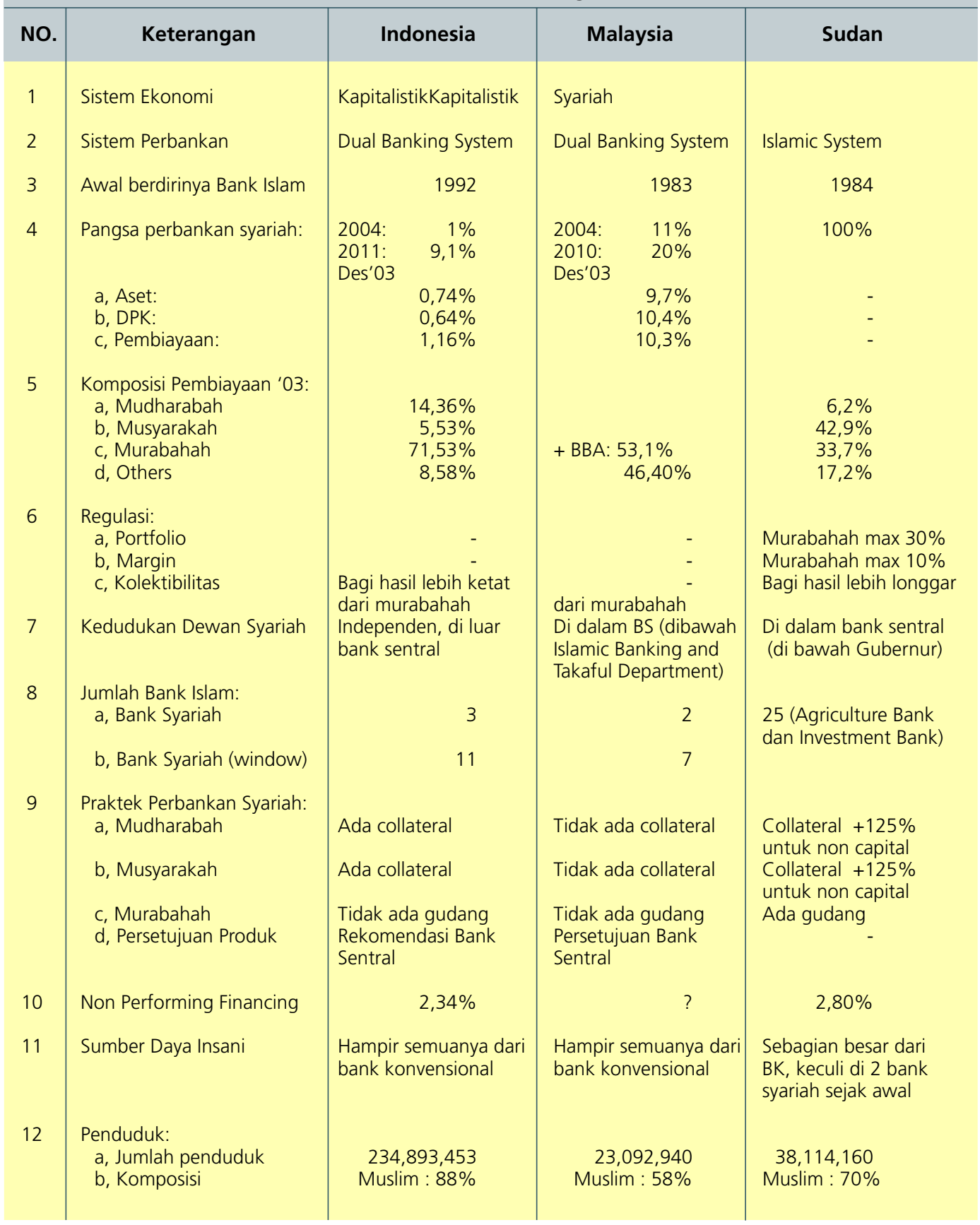




\section{BERBAGAI PENYEBAB RENDAHNYA PEMBIAYAAN BAGI HASIL}

Rendahnya pembiayaan bagi hasil atau dominasi pembiayaan nonbagi hasil pada portfolio pembiayaan bank syariah ternyata merupakan fenomena global yang terjadi tidak hanya di perbankan syariah di Indonesia, melainkan juga terjadi di perbankan syariah di seluruh dunia. Lebih jauh lagi, fenomena ini terjadi tidak hanya di bank syariah yang baru atau belum lama berdiri (yang masih dalam masa transisi), melainkan juga terjadi di bank syariah yang sudah cukup lama berdiri (yang sudah dianggap established). Namun demikian, menurut Chapra (2000) tahap-tahap kearah perbaikan telah tampak. Sebagai contoh, dari data International Association of Islamic Banks atau IAIB tahun 1996, proporsi murabahah yang sebelumnya mencapai 90\% dari total pembiayaan telah turun menjadi 40,3\%. Sementara itu, pembiayaan mudharabah dan musyarakah telah meningkat menjadi 7,2\% dan 12,7\%. Namun, penggunaan pembiayaan bagi hasil di perbankan syariah masih sangat marginal, yang angkanya masih dibawah 20\%.

Permasalahan penggunaan pembiayaan bagi hasil yang masih sangat rendah ini merupakan masalah yang tidak sederhana, bahkan merupakan masalah yang memiliki multi dimensi. Beberapa pakar telah mencoba mengidentifikasi sumber-sumber penyebab terjadinya masalah yang kelihatannya sulit diuraikan ini. Dari berbagai pendapat pakar ${ }^{3}$, penyebab rendahnya pembiayaan bagi hasil dapat dilihat dari empat sisi, yaitu: 1) internal bank syariah; 2) nasabah; 3) regulasi; dan 4) pemerintah dan institusi lain, dengan rincian sebagai berikut:

\section{a. Internal bank syariah:}

1. Kualitas sumber daya insani (SDI) yang belum memadai untuk menangani, memproses, memonitor, menyelia, dan mengaudit berbagai proyek bagi hasil;

2. Aversion to effort, karena penanganan pembiayaan bagi hasil tidak semudah penanganan pembiayaan sekunder;

3. Berkurangnya fleksibilitas dalam penggunaan dana, karena pembiayaan bagi hasil bersifat full-equity based investment,

4. Aversion to risk karena takut kehilangan kepercayaan dari depositor ketika tingkat bagi hasil menurun;

5. Bank syariah belum dapat menanggung risiko besar, karena belum memiliki bentuk keahlian yang dibutuhkan untuk memproses, memonitor, menyelia dan mengaudit berbagai proyek bagi risiko;

6. Adverse selection, karena pengusaha yang menjalankan usaha yang menguntungkan enggan untuk membagi keuntungannya yang besar dengan bank syariah ketika pembiayaan dengan bunga masih memungkinkan; dan

3 Diantaranya Chapra (2000), Iqbal dan Llewellyn (2002), Dar dan Presley (2000), Sarker (1999), Algaoud dan Lewis (2001), Mulyawan (2001), Al-Jarhi (2002), dan Parinduri (2003). 
7. Kompetisi ketat dengan bank konvensional memaksa bank syariah harus menyediakan pembiayaan alternatif yang berisiko lebih kecil;

8. Tidak dapat membiayai modal kerja usaha, karena fleksibilitas dari fasilitas overdraft tidak mudah ditiru menurut ketentuan Islam;

9. Tidak dapat membiayai usaha kecil, karena tidak adanya personal guarantee maupun collateral;

10.Tidak dapat membiayai proyek jangka panjang, karena rumit dan makan waktu dari sisi prosedur, kurangnya pengalaman dan keahlian SDI, dan kurangnya fleksibilitas penggunaan dana akibat modal tertanam untuk jangka waktu lama;

11.Tidak dapat membiayai proyek jangka pendek, karena tingginya risiko;

12.Keterbatasan peran bank sebagai investor (ketidakseimbangan hak-hak manajemen dan kontrol), terutama dalam hal pembiayaan mudharabah;

13.Biaya informasi yang meningkat, terutama dengan pembiayaan mudharabah;

14.Tidak adanya buku petunjuk syariah yang lengkap dan komprehensif untuk memudahkan pelaksanaan;

15.Tidak adanya metodologi analisa dan pengukuran risiko investasi syariah untuk analisa yang lebih baik; dan

16.Tidak adanya petunjuk manajemen syariah yang lengkap dan komprehensif untuk memudahkan manajemen.

\section{b. Nasabah bank Syariah:}

1. Sebagian nasabah penyimpan/peminjam bersifat risk averse, karena belum terbiasa dengan kemungkinan rugi dan sudah terbiasa dengan sistem bunga;

2. Moral hazard, karena pengusaha enggan menyampaikan laporan keuangan/keuntungan yang sebenarnya untuk menghindar pajak dan untuk menyembunyikan keuntungan yang sebenarnya;

3. Permintaan pembiayaan bagi hasil masih kecil dari nasabah.

\section{c. Regulasi:}

1. Kurangnya dukungan dari regulator, karena tidak melakukan inisiatif-inisiatif untuk mengadakan perubahan-perubahan peraturan dan institusional yang diperlukan untuk mendukung bekerjanya sistem perbankan syariah dengan baik;

2. Tidak adanya institusi pendukung untuk mendorong penggunaan bagi hasil; dan

3. Tidak adanya prosedur operasional yang seragam;

\section{d. Pemerintah dan Institusi lain:}

1. Tidak ada kebijakan pendukung yang mendorong penggunaan pembiayaan bagi hasil untuk proyek-proyek pemerintah; 
2. Perlakuan pajak yang tidak adil, yang memperlakukan keuntungan sebagai obyek pajak sedangkan bunga bebas dari pajak;

3. Pasar sekunder instrumen keuangan syariah belum ada, sehingga menyulitkan bank untuk menyalurkan atau mendapatkan akses likuiditas sesuai Syariah;

4. Hak kepemilikan yang tidak jelas, karena pembiayaan bagi hasil memerlukan adanya hak kepemilikan yang jelas dan berlaku efisien; dan

5. Tidak adanya satu kata dalam aturan-aturan syariah;

\section{ANALISIS RENDAHNYA PEMBIAYAAN BAGI HASIL}

Masalah rendahnya pembiayaan bagi hasil atau dominasi pembiayaan nonbagi hasil, khususnya murabahah, di perbankan syariah Indonesia akan dianalisis dengan menggunakan Analytic Network Process (ANP). Setelah memperoleh data dan informasi dari FGD dan indepth interview, terdapat empat langkah utama yang harus dilakukan dalam analisis ini. Pertama adalah merancang kerangka ANP dari masalah yang akan dianalisis, lengkap dengan semua cluster, elemen, dan hubungan-hubungannya. Kedua adalah mengumpulkan data melalui kuesioner, yang dirancang sesuai dengan kerangka jaringan feedback yang telah dibuat, yang diisi oleh pihak-pihak yang ahli di bidang perbankan syariah, yaitu kalangan perbankan syariah dan para pakar. Ketiga adalah memproses data dengan kerangka ANP menggunakan perangkat lunak ANP. Keempat adalah menganalisis tiga supermatrix (unweighted, weighted, dan limiting) yang dihasilkan yang selanjutnya dipergunakan sebagai dasar untuk memberikan policy recommendation yang sesuai untuk mengatasi masalah yang ada.

\section{V.1 Kerangka ANP}

ANP merupakan gabungan dari dua bagian. Bagian pertama terdiri dari hierarki kontrol atau jaringan dari kriteria dan subkriteria yang mengontrol interaksi. Bagian kedua adalah jaringan pengaruh-pengaruh diantara elemen dan cluster. Jaringan feedback pada gambar II.2 memperlihatkan kerangka umum untuk analisis. Jaringan ini memiliki 5 buah cluster yaitu: 1) tujuan, 2) aspek, 3) masalah, 4) pemecahan, dan 5) strategi. Cluster "aspek" memiliki empat elemen, cluster "masalah" memiliki sepuluh elemen, cluster "pemecahan" memiliki lima elemen, dan cluster "strategi" memiliki tiga elemen. Secara lebih rinci, jaringan feedback yang digunakan dalam analisis ini diperlihatkan pada gambar II.3 dan gambar II.4.

Seperti dikemukakan pada bab 4, masalah rendahnya pembiayaan bagi hasil dapat dilihat dari empat sisi atau aspek, yaitu aspek internal bank syariah, aspek nasabah, aspek regulasi, dan aspek pemerintah dan institusi lain. 
Dari hasil FGD dan indepth interview, masalah-masalah pada masing-masing aspek mengerucut pada sepuluh masalah utama yang meliputi lima masalah dari sisi internal bank syariah, dua masalah dari sisi nasabah, dua masalah dari sisi regulasi, dan satu masalah dari sisi pemerintah dan institusi lain.

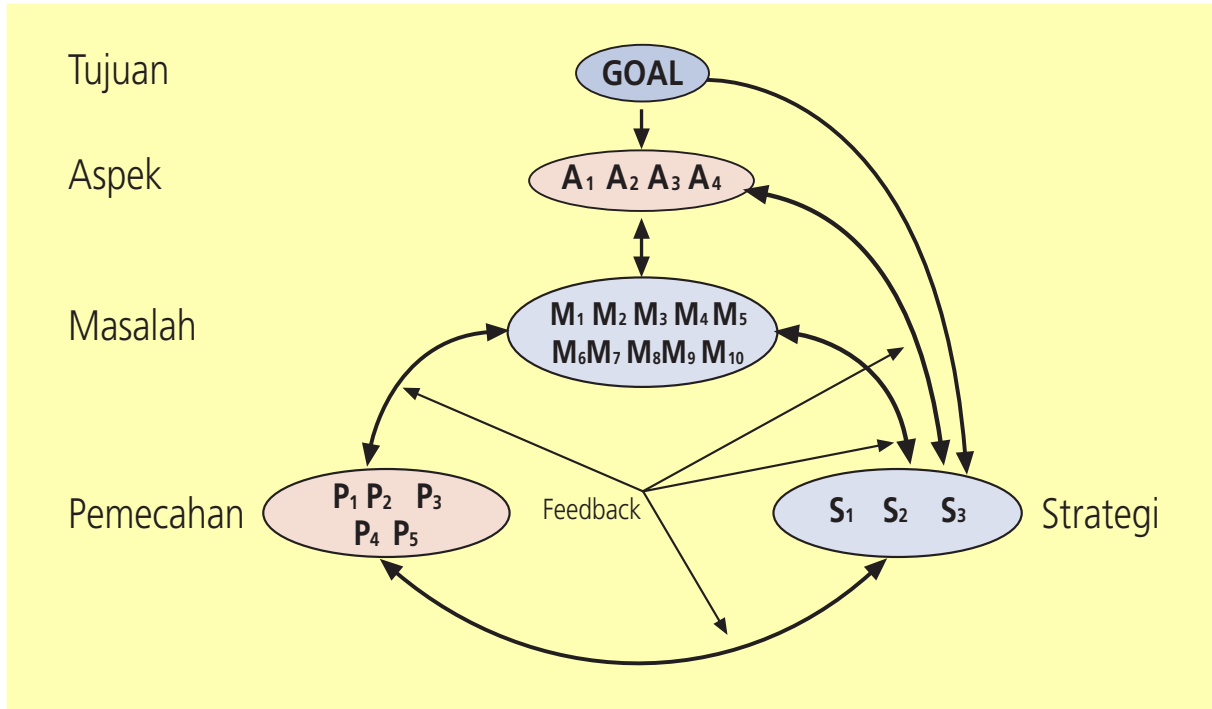

Gambar II.2 Jaringan Feedback Rendahnya Pembiayaan Bagi Hasil 1

a. Internal:

1) Pemahaman terhadap esensi bank syariah kurang; 2) Orientasi bisnis lebih diutamakan;

3) Kualitas dan kuantitas SDI belum memadai; 4) Bank syariah masih bersikap averse to effort, dan 5) Bank syariah masih bersikap averse to risk.

\section{b. Nasabah:}

1) Pemahaman nasabah terhadap esensi bank syariah yang masih rendah; dan

2) Nasabah masih bersikap averse to risk.

\section{c. Regulasi:}

1) Kurangnya insentif untuk mendorong pembiayaan bagi hasil; dan

2) Kurangnya kebijakan pendukung.

\section{d. Pemerintah dan Institusi Lain:}

1) Kurangnya komitmen dan dukungan pemerintah yang menyeluruh. 


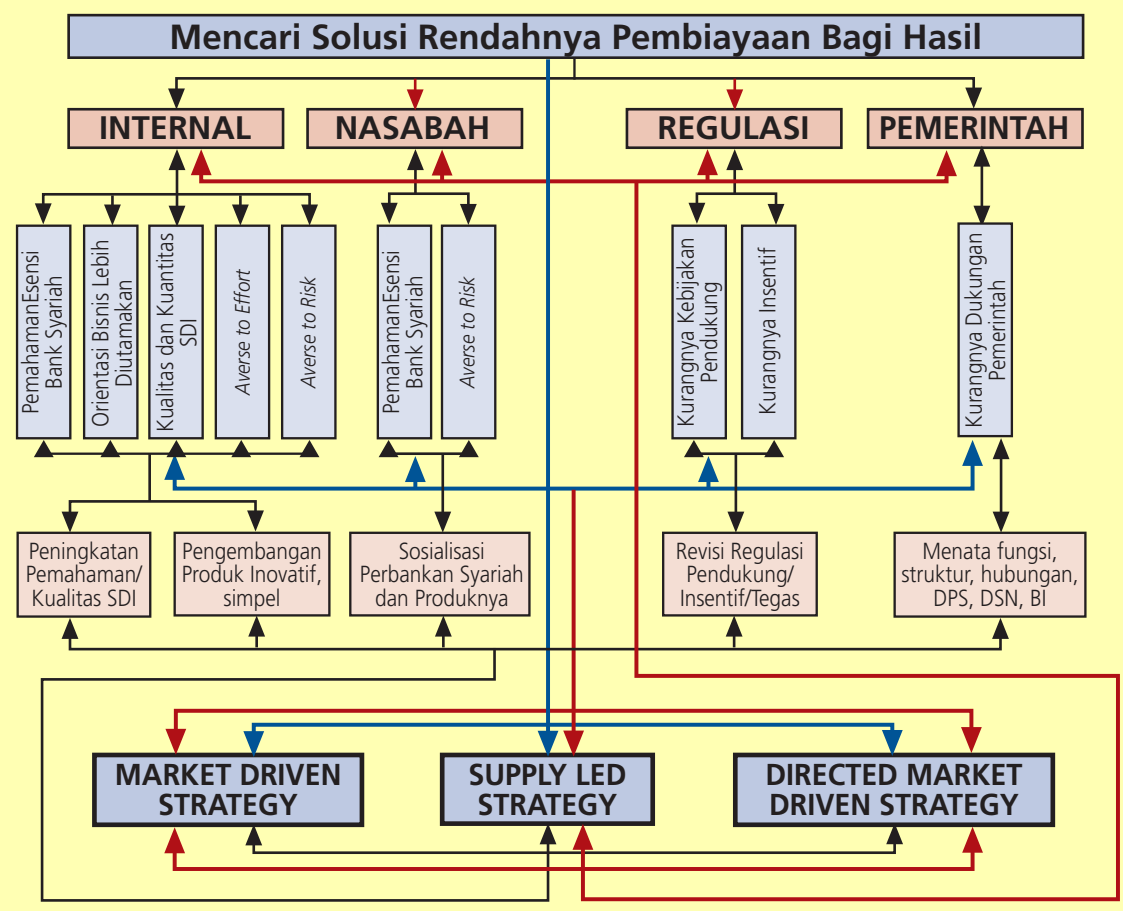

Gambar II.3 Jaringan Feedback Rendahnya Pembiayaan Bagi Hasil 2

Dari hasil FGD dan indepth interview, berbagai usulan alternatif solusi pemecahan masalah pada akhirnya dapat dirangkum menjadi lima alternatif:

1. Peningkatan pemahaman/kualitas SDI (internal);

2. Pengembangan produk yang menarik dan simpel (internal);

3. Sosialisasi perbankan syariah dan produknya (nasabah);

4. Revisi semua regulasi yang kurang mendukung, memberlakukan sistem insentif, dan/atau menerapkan regulasi tegas (regulasi); dan

5. Menata kembali fungsi, struktur, dan hubungan DSN, DPS, BI, (dan Konsultan, jika memungkinkan) agar tercipta sinergi yang harmonis (pemerintah/institusi lain). 


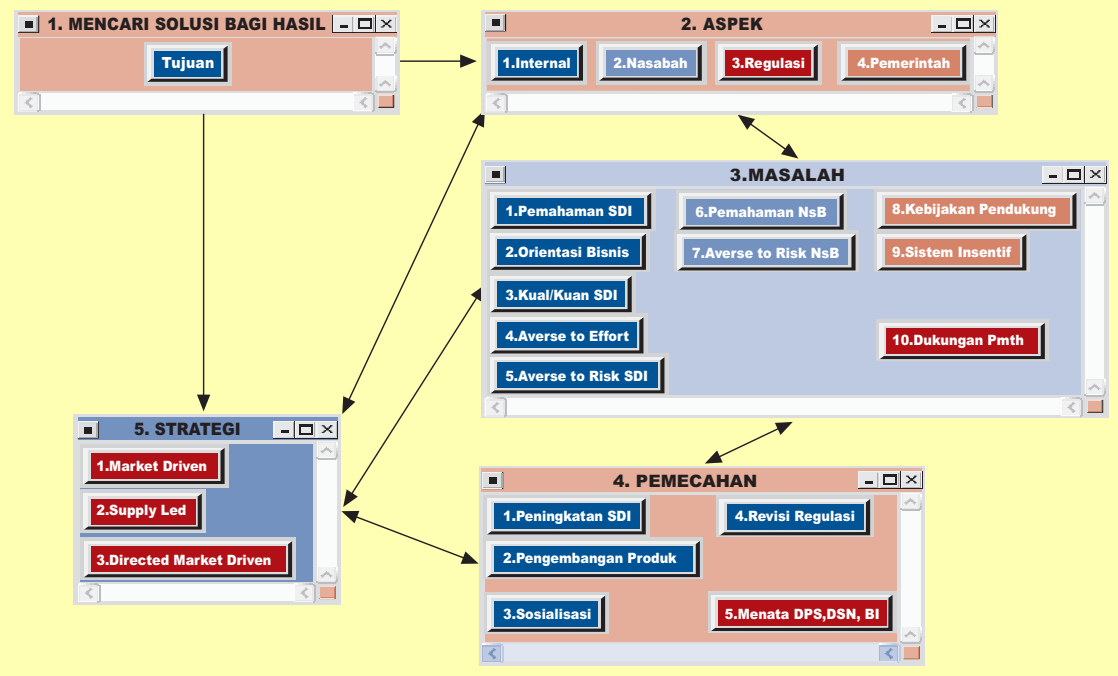

Gambar II.4 Jaringan Feedback Rendahnya Pembiayaan Bagi Hasil 3

Lebih jauh lagi, untuk mengembangkan perbankan syariah Indonesia menuju the real Islamic bank yang diinginkan, dan khususnya untuk meningkatkan porsi pembiayaan bagi hasil, tiga strategi pengembangan diusulkan:

1. Market driven strategy, yaitu strategi mengikuti keinginan/keadaan pasar sehingga diharapkan pemerintah/regulator tidak membuat kebijakan/regulasi langsung yang mengandung unsur intervensi yang akan mengganggu pasar, namun sebaliknya membuat regulasi agar mekanisme pasar berjalan lancar;

2. Supply led strategy, yaitu strategi untuk mengarahkan pasar sesuai dengan tujuan yang ingin dicapai oleh pemerintah/regulator dengan membuat regulasi-regulasi langsung ke arah tujuan; dan

3. Directed market driven strategy, yaitu strategi mengikuti pasar dengan mengarahkan secara tidak langsung kearah yang diinginkan.

\section{V.2 Data Kuesioner}

Dalam rangka mendapatkan data primer tentang persepsi para pakar dan kalangan perbankan syariah terhadap masalah rendahnya pembiayaan bagi hasil di perbankan syariah Indonesia, dalam kerangka model ANP yang telah dirancang, survey menggunakan kuesioner dilakukan. Responden terdiri dari kalangan pakar dan perbankan di DKI dan sekitarnya. 
Dalam analisis ANP jumlah sampel/responden tidak digunakan sebagai patokan validitas. Syarat responden yang valid dalam ANP adalah bahwa mereka adalah orang-orang yang ahli di bidangnya. Oleh karena itu, responden yang dipilih dalam survey ini adalah para pakar perbankan syariah dan para 'syariah bankers' yang sehari-harinya berkecimpung dengan segala urusan bank syariah.

Pertanyaan dalam kuesioner ANP berupa pairwise comparison (pembandingan pasangan) antar elemen dalam cluster untuk mengetahui mana diantara keduanya yang lebih besar pengaruhnya (lebih dominan) dan seberapa besar perbedaannya (pada skala 1-9) dilihat dari satu sisi. Skala numerik 1-9 yang digunakan merupakan terjemahan dari penilaian verbal seperti pada tabel II.5.

Tabel II. 5

Perbandingan Skala Verbal dan Skala Numerik

\begin{tabular}{l|c} 
Skala Penilaian Verbal & Skala numerik \\
Amat sangat lebih besar pengaruhnya & 9 \\
Sangat lebih besar pengaruhnya & 8 \\
& 7 \\
Lebih besar pengaruhnya & 6 \\
Sedikit lebih besar pengaruhnya & 5 \\
& 4 \\
Sama besar pengaruhnya & 3 \\
\end{tabular}

Sebagai contoh, empat elemen dalam cluster "aspek" dipasang-bandingkan dilihat dari sisi pencapaian tujuan, sehingga pertanyaan untuk membandingkan aspek 'internal bank syariah' dan 'nasabah' menjadi: "Dalam rangka memecahkan masalah RENDAHNYA PEMBIAYAAN BAGI HASIL, dari kedua ASPEK dibawah ini mana yang lebih besar pengaruhnya (lebih dominan), dan berapa besar perbedaannya"

Lebih besar pengaruhnya daripada

dengan skala

\begin{tabular}{|l|l|l|l|l|l|l|l|l|l|l|l|l|l|l|l|l|l|l|l|}
\hline $\begin{array}{l}\text { Internal bank } \\
\text { syariah }\end{array}$ & $\mathbf{9}$ & $\mathbf{8}$ & $\mathbf{7}$ & $\mathbf{6}$ & $\mathbf{5}$ & $\mathbf{4}$ & $\mathbf{3}$ & $\mathbf{2}$ & $\begin{array}{c}1 \\
\text { (equal) }\end{array}$ & $\mathbf{2}$ & $\mathbf{3}$ & $\mathbf{4}$ & $\mathbf{5}$ & $\mathbf{6}$ & $\mathbf{7}$ & $\mathbf{8}$ & $\mathbf{9}$ & Nasabah \\
\hline
\end{tabular}

$\rightarrow$ Lebih kecil pengaruhnya daripada dengan skala 
Apabila aspek 'internal bank syariah' sangat lebih besar pengaruhnya dari pada aspek 'nasabah' maka responden memilih angka 7 pada sisi kiri. Apabila aspek 'nasabah' sedikit lebih besar pengaruhnya dari pada aspak 'internal bank syariah' maka responden memilih angka 3 pada sisi kanan.

Angka-angka yang diperoleh dari hasil kuesioner masing-masing responden kemudian dipergunakan dalam sintesis ANP untuk menghasilkan tiga supermatrix yang akan memberikan prioritas masalah, alternatif pemecahan masalah dan pilihan strategi kebijakannya.

\section{V.3 Hasil ANP}

Output hasil sintesis dari ANP berupa tiga supermatrix yang bersifat stokastik. Contoh limiting supermatrix yang dihasilkan oleh ANP dapat dibaca pada Lampiran II.3 sebagai bahan menganalisa hasilnya.

\section{V.3.1 Karakteristik Responden}

Pada dasarnya responden yang diambil dalam survey ini adalah merupakan responden FGD dan indepth interview yang dianggap paling paham tentang perbankan syariah ditambah dengan beberapa responden lain yang dianggap memiliki pemahaman yang mendalam tentang perbankan syariah. Jumlah responden dalam survey ini meliputi sembilan orang pakar dan sembilan orang wakil dari BUS dan UUS. Responden pakar merupakan orang pilihan yang mewakili berbagai kalangan baik akademisi, praktisi, pemerintah, maupun ulama. Sedangkan responden perbankan juga merupakan orang pilihan yang mewakili semua BUS dan UUS yang sudah cukup lama beroperasi, dengan jabatan minimal setingkat kepala divisi sampai dengan direktur utama.

Dalam metode ANP jumlah responden tidak penting, yang paling penting adalah responden yang dipilih merupakan orang yang menguasai dan kompeten pada bidangnya. Dari kalangan perbankan, dipilih sembilan responden yang mewakili tiga BUS yaitu Bank Syariah Mandiri, Bank Muamalat Indonesia dan Bank Syariah Mega Indonesia, dan enam UUS yang sudah lama beroperasi yaitu Bank BNI Syariah, Bank IFI Syariah, BRI Syariah, Bank Bukopin Syariah, Bank Danamon Syariah, dan Bll Syariah. Sedangkan dari kalangan pakar, dipilih responden dengan jumlah yang sama dengan jumlah responden dari kalangan perbankan dengan alasan untuk menjaga keseimbangan jumlah responden dan mempermudah dalam melakukan analisis. 


\section{V.3.2 Pengolahan Data}

Hasil survey yang diperoleh diolah terlebih dahulu per masing-masing individu responden dengan menggunakan kerangka ANP seperti disajikan pada gambar II.3 dan II.4. Data yang diolah dari masing-masing responden tersebut menghasilkan tiga supermatriks yang memberikan urutan prioritas aspek-aspek terpenting dan masalahnya, alternatif pemecahan masalah, dan pilihan strategi kebijakan yang tepat menurut masing-masing responden.

Selanjutnya hasil pengolahan tersebut dikelompokkan menjadi kelompok pakar dan kelompok perbankan untuk menghasilkan urutan prioritas berdasarkan kelompok. Untuk memperoleh hasil tersebut, dari sembilan responden dalam satu kelompok dihitung rata-rata dan modusnya. Nilai rata-rata dan/atau modus ${ }^{4}$ inilah yang digunakan untuk menentukan urutan prioritas.

Disamping hasil urutan prioritas berdasarkan masing-masing kelompok, dihitung juga urutan prioritas secara keseluruhan. Hal ini dilakukan dengan membuat rata-rata maupun mencari modus dari keseluruhan responden sebanyak 18 orang tersebut.

\section{V.3.3 Hasil ANP}

Data yang telah diolah seperti disebutkan diatas menghasilkan tabel ANP sebagaimana berikut:

4 Dalam metode ANP, data yang diperlukan dapat diperoleh melalui dua cara. Pertama, satu data yang diperoleh merupakan konsensus dari sekelompok responden yang dikumpulkan secara bersamaan. Kedua, pengumpulan data dilakukan secara terpisah untuk masingmasing responden, dalam kasus ini metode ANP membolehkan menggunakan modus atau rata-rata untuk mendapatkan satu hasil urutan prioritas. 


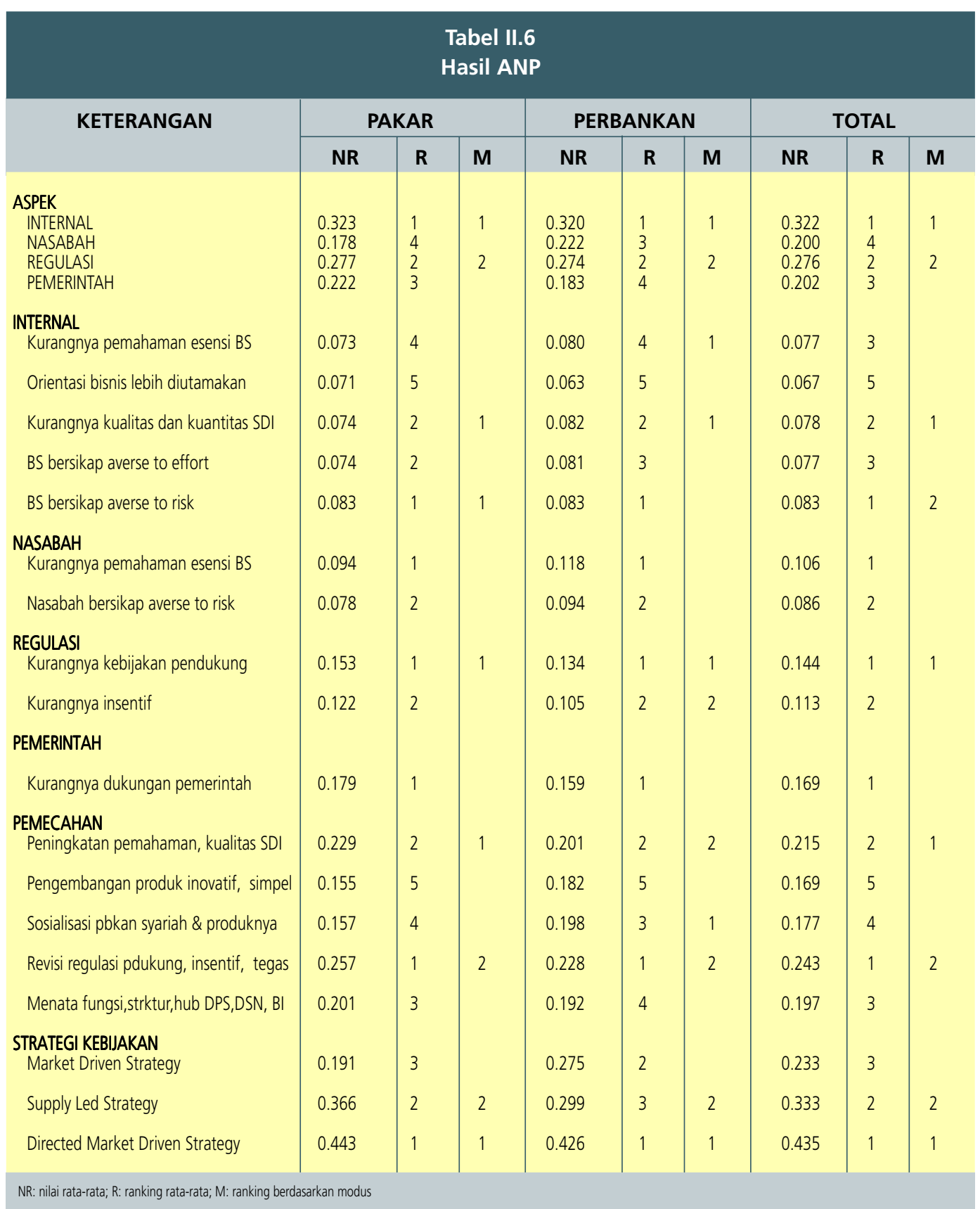

\section{a. Menurut Pakar}

Masalah utama rendahnya pembiayaan bagi hasil di perbankan syariah Indonesia terletak pada aspek internal perbankan dan regulasi. Dari aspek internal perbankan, masalah utama yang dianggap paling penting adalah bank syariah yang masih bersikap averse to risk dan 
kurangnya kualitas dan kuantitas SDI. Sedangkan dari aspek regulasi, kurangnya kebijakan pendukung merupakan hal yang utama.

Untuk menanggulangi masalah tersebut kalangan pakar berpendapat bahwa solusi yang menjadi prioritas utama adalah solusi meningkatkan pemahaman dan kualitas SDI perbankan syariah di semua level jabatan dan menyempurnakan regulasi yang bersifat mendorong peningkatan pembiayaan bagi hasil serta memberikan insentif bagi kalangan perbankan syariah.

Usulan solusi untuk menanggulangi permasalahan tersebut diatas menurut pakar akan lebih efektif apabila dilaksanakan secara tidak langsung dengan menggunakan directed market driven strategy. Hasil pandangan pakar tersebut diatas tidak berbeda apabila dilihat dari ratarata maupun modus.

\section{b. Menurut Perbankan}

Sama halnya dengan pandangan pakar, masalah utama rendahnya pembiayaan bagi hasil menurut perbankan juga terletak pada aspek internal perbankan dan regulasi. Perbedaannya terletak dari aspek internal perbankan yang lebih menekankan kepada masalah kurangnya pemahaman esensi bank syariah. Disamping itu kalangan perbankan juga memandang masalah kurangnya kualitas dan kuantitas SDI di perbankan syariah (jika dilihat berdasarkan modus). Jika dilihat berdasarkan rata-rata, masalah utamanya adalah kecenderungan bank syariah yang averse to risk.

Untuk menanggulangi masalah tersebut kalangan perbankan berpendapat bahwa solusi yang menjadi prioritas utama adalah sosialisasi perbankan syariah dan produknya serta meningkatkan pemahaman mengenai esensi perbankan syariah kepada semua level jabatan di perbankan syariah. Sedangkan urutan prioritas pemecahan masalah berdasarkan rata-rata, kalangan perbankan cenderung mengutamakan penyempurnaan regulasi baru peningkatan pemahaman, tidak berbeda dengan urutan prioritas berdasarkan pendekatan modus.

Usulan solusi untuk menanggulangi permasalahan tersebut diatas kalangan perbankan berpendapat sama dengan kalangan pakar yaitu dengan menggunakan directed market driven strategy.

\section{c. Hasil Keseluruhan Responden}

Jika dilihat hasil perhitungan responden secara keseluruhan, tampak bahwa urutan prioritasnya tidak berbeda dengan pendapat pakar. Dimana masalah utama terletak pada aspek internal perbankan dan regulasi. 
Kurangnya kualitas dan kuantitas SDI serta kecenderungan perbankan syariah yang averse to risk merupakan masalah utama dalam aspek internal perbankan. Sedangkan permasalahan utama dariaspek regulasi adalah kurangnya kebijakan yang mendukung. Oleh sebab itu solusi yang paling utama untuk menangani kedua permasalahan tersebut adalah meningkatkan pemahaman dan kualitas SDI serta penyempurnaan regulasi yang mendorong peningkatan pembiayaan bagi hasil serta memberikan insentif bagi kalangan perbankan syariah.

Strategi yang sesuai dengan kondisi diatas adalah dengan menerapkan directed market driven strategy.

\section{V.3.4 Analisis Hasil ANP}

Dari hasil ANP diatas, terlihat bahwa antara kalangan perbankan dan pakar memiliki persepsi yang sama dalam melihat permasalahan rendahnya pembiayaan bagi hasil di perbankan syariah Indonesia yaitu terpusat pada aspek internal perbankan dan regulasi.

Pada aspek internal perbankan, kurangnya pemahaman, kualitas, dan kuantitas SDI di perbankan syariah merupakan permasalahan utama. Kurangnya pemahaman SDI perbankan syariah terutama disebabkan karena hampir semua SDI perbankan syariah berasal dari perbankan konvensional sehingga perilaku mereka cenderung seperti perilaku seorang conventional bankers, bukan Islamic bankers. Selain itu, rendahnya kualitas SDI perbankan syariah, selain karena mereka datang dari bank konvensional, pada umumnya mereka tidak diberi training yang memadai sebagai bekal mereka untuk dapat bekerja dengan baik sebagai Islamic bankers. Hal ini selaras dengan pendapat sebagian pakar bahwa pangkal masalah yang timbul di internal perbankan syariah adalah masalah paradigma atau mindset. Mereka berpendapat apabila masalah ini dapat terselesaikan, maka masalah-masalah lain akan terpecahkan atau menjadi bukan masalah lagi.

Pengalaman di negara Sudan menunjukkan bahwa keberhasilan dari pembiayaan bagi hasil (mudharabah dan musyarakah) sangat ditentukan oleh pihak perbankan yang benarbenar memahami seluk-beluk bisnis yang akan dibiayai. Sehingga perbankan yang sukses dalam menyalurkan pembiayaan berbasis bagi hasil adalah perbankan yang dari awalnya memang berbisnis secara syariah, dimana para bankersnya memiliki pengalaman bisnis yang mendalam, sehingga tidak berperilaku menghindar dari risiko. Dalam kaitannya dengan hasil survey menunjukkan bahwa bank syariah di Indonesia cenderung menghindari risiko. Kondisi ini tidak terlepas dari keterbatasan SDI yang ada di perbankan syariah. Hal ini sangat terkait erat dengan paradigma konvensional yang dibawa oleh SDI ketika mereka pindah ke perbankan syariah. Oleh sebab itu perubahan cara berpikir atau paradigma dari konvensional ke syariah dari SDI 
perbankan syariah sepertinya diperlukan untuk dapat mengatasi masalah-masalah SDI ini, masalah-masalah internal perbankan syariah lainnya, maupun beberapa masalah eksternal yang dirasa memberatkan. Sebagai contoh, ketentuan mengenai jaminan untuk pembiayaan bagi hasil di Sudan dipatok sebesar 125\%, dan jaminan ini bukan untuk menjamin modal atau capital, melainkan untuk menjamin penyalahgunaan atau kelalaian nasabah. Namun demikian, hal ini tidak menjadi hambatan bagi bank maupun nasabah untuk memilih pembiayaan bagi hasil.

Dari aspek regulasi pun antara perbankan maupun pakar memiliki persepsi yang sama, yaitu kebijakan yang ada kurang mendukung terhadap penyaluran pembiayaan bagi hasil. Salah satu contoh kebijakan yang paling banyak disoroti adalah masalah ketentuan kolektabilitas bagi skim pembiayaan mudharabah dan musyarakah yang dirasa memberatkan bank. Apabila hal ini memang merupakan keadaan yang dirasakan oleh sebagian besar pelaku perbankan syariah, maka aturan-aturan yang kurang mendukung perlu untuk dievaluasi kembali. Sementara itu, ketentuan-ketentuan yang bersifat mendorong dan memberi insentif untuk penyaluran pembiayaan bagi hasil perlu dipertimbangkan. Dalam hal ini kebijakan BOS dapat juga dipergunakan sebagai bahan pertimbangan dimana tingkat peringatan kolektibilitas untuk pembiayaan bagi hasil dibuat lebih longgar dari pembiayaan murabahah. Pembiayaan mudharabah dan musyarakah diklasifikasikan lancar sampai dengan tiga bulan setelah jangka waktu berakhir, tanpa melihat kondisi pembiayaan maupun bagi hasil yang diberikan (untung/ rugi). Sementara itu, pembiayaan murabahah sudah dapat diklasifikasikan sebagai non performing (kurang lancar) apabila terdapat tunggakan yang melebihi satu bulan.

Masalah berikutnya yang perlu juga mendapat perhatian adalah kurangnya dukungan pemerintah dan institusi terkait yang menyeluruh yang juga menghambat penyaluran pembiayaan bagi hasil. Salah satunya adalah belum jelasnya fungsi, struktur, dan hubungan antara Dewan Syariah Nasional (DSN), Dewan Pengawas Syariah (DPS), dan Bank Indonesia sebagai regulator dan pengawas. Kejelasan fungsi, struktur, dan hubungan diantara institusi terkait tersebut sangat diperlukan agar kerjasama yang sinergis dan harmonis dapat tercipta untuk bersama-sama mendorong penyaluran pembiayaan bagi hasil. Beberapa negara, seperti Malaysia dan Sudan, menempatkan DSN di dalam bank sentral sehingga kerja sama lebih efektif. Untuk itu perlu dilakukan kajian apakah hal ini dapat diterapkan di Indonesia.

Dilihat dari sisi sumber permasalahan antara perbankan dengan pakar memiliki persepsi yang sama, namun dalam hal solusi yang perlu diambil untuk menyelesaikan masalah tersebut, antara perbankan dengan pakar terdapat perbedaan. Dari sisi pakar solusi yang harus ditempuh adalah dengan meningkatkan pemahaman dan kualitas SDI, serta merevisi regulasi pendukung dan memberikan insentif untuk mendorong perbankan syariah meningkatkan pembiayaan bagi 
hasilnya. Sementara itu, dari sisi perbankan cenderung untuk menggalakkan sosialisasi perbankan syariah dan produknya kepada masyarakat, sedangkan masalah SDI dan regulasi ditempatkan pada prioritas kedua. Hal ini cukup mengagetkan, karena diawal permasalahan yang menjadi prioritas adalah masalah internal, namun solusi yang dikemukakan lebih untuk nasabah. Hasil ini memberikan indikasi bahwa kalangan perbankan masih reluctant untuk memperbaiki kondisi kualitas SDI-nya, meskipun hal itu disadari merupakan suatu masalah yang penting. Namun demikian, secara keseluruhan alternatif pemecahan yang diusulkan sejalan dengan masalah yang dianggap penting.

Sehingga dapat disimpulkan bahwa masalah utama rendahnya pembiayaan bagi hasil disebabkan oleh masalah internal yang menyangkut pemahaman dan kualitas SDI, serta masalah eksternal yang menyangkut regulasi yang kurang mendukung. Alternatif pemecahannya dari sisi internal dengan meningkatkan pemahaman dan kualitas SDI, sedangkan dari sisi eksternal dengan meninjau kembali regulasi yang ada dan mengeluarkan aturan insentif.

Dengan masalah dan alternatif pemecahan yang diajukan, kalangan pakar dan perbankan menyepakati bahwa strategi pemecahan yang sesuai adalah dengan menerapkan directed market driven strategy, dimana regulator tidak melepaskan begitu saja perkembangan dan praktek perbankan syariah kepada pasar, tetapi tidak juga mengekang gerak perbankan syariah, namun dengan memberikan arahan serta target indikatif yang harus dicapai oleh perbankan syariah. Sama seperti kebijakan yang diambil oleh otoritas perbankan di Sudan, dimana Bank of Sudan memberikan target indikatif terhadap porsi maksimal pembiayaan murabahah (nonbagi hasil) yang boleh dimiliki oleh perbankan syariah disana.

\section{KESIMPULAN DAN REKOMENDASI}

\section{VI.1 Kesimpulan}

Dari pembahasan pada bab-bab terdahulu dapat ditarik beberapa kesimpulan antara lain:

1. Masalah dominasi pembiayaan nonbagi hasil atau rendahnya pembiayaan bagi hasil di perbankan syariah seyogyanya dilihat secara proporsional karena beberapa hal. Pertama, masalah ini hanyalah satu dari sekian banyak masalah yang saling kait-mengait yang dihadapi oleh perbankan syariah. Namun demikian masalah ini harus juga mendapat perhatian yang serius karena masalah ini juga dapat mendatangkan reputation risk sebagai akibat label syariah yang menempel pada lembaga keuangan ini.

2. Kedua, masalah ini sebenarnya bukanlah masalah yang sifatnya esensial (ushul), namun sifatnya cabang (furu'), karena pembiayaan bagi hasil dan nonbagi hasil sama-sama 
diperbolehkan secara Syariah. Namun, sebagian pakar berpendapat bahwa pembiayaan nonbagi hasil, khususnya murabahah, merupakan bentuk pembiayaan sekunder yang mestinya dipergunakan sementara saja pada masa awal pertumbuhan sebelum bisa menggunakan pembiayaan bagi hasil, dan/atau porsinya semestinya tidak mendominasi pembiayaan keseluruhan. Selain itu, pandangan mainstream berpendapat bahwa bentuk pembiayaan bagi hasil-lah yang menceminkan the real islamic bank.

3. Ketiga, masalah dominasi nonbagi hasil, khususnya murabahah, merupakan masalah yang menyertai perkembangan suatu bank syariah, karena pada tahap awal pertumbuhan (formatif) bank syariah harus menghadapi berbagai masalah lain yang menyertai pertumbuhan, khususnya membangun SDI dengan paradigma baru yang sesuai dengan tuntutan Syariah. Namun apabila dibiarkan tanpa arahan, masalah ini dapat menjadi berkepanjangan, atau dianggap sebagai bukan masalah, seperti keadaan di Malaysia.

4. Keempat, masalah rendahnya pembiayaan bagi hasil merupakan fenomena global yang tidak hanya terjadi di Indonesia, tetapi juga terjadi di negara-negara lain yang menerapkan dual banking system maupun fully Islamic banking/financial system, namun negara yang menerapkan fully Islamic banking/financial system mempunyai kemungkinan lebih besar untuk dapat mengatasi masalah ini, karena perangkat dan infrastrukturnya yang mendukung. Sudan dapat digunakan sebagai contoh negara yang berhasil meningkatkan pembiayaan bagi hasil di perbankan syariahnya.

5. Sebagian pakar berpendapat bahwa masalah-masalah yang ada di perbankan syariah berawal dari satu hal pokok yaitu paradigma atau mindset para pelakunya, khususnya SDI perbankan syariah. Apabila pokok masalah ini terselesaikan sebenarnya masalah-masalah lain menjadi hilang dengan sendirinya. Contoh di Sudan menunjukkan bahwa bank yang dari awal berprinsip syariah terbukti tidak mengalami banyak kesulitan dan sukses dalam menyalurkan pembiayaan bagi hasil, sedangkan bank yang harus mengkonversi diri menjadi bank syariah, karena peraturan, tidak begitu sukses dilapangan. Perusahaan modal ventura syariah di Indonesia juga tidak mengalami kesulitan dengan bagi hasil.

6. Masalah lain yang lebih penting menurut sebagian pakar adalah masalah kemurnian pembiayaan murabahah, karena disinyalir murabahah dipraktekkan tidak sesuai dengan murabahah yang sebenarnya. Hal ini perlu segera mendapat perhatian yang sungguhsungguh.

7. Masalah rendahnya pembiayaan bagi hasil, dalam penelitian ini, pada akhirnya mengerucut pada dua masalah pokok dari aspek internal perbankan dan regulasi, yaitu masalah kurangnya pemahaman dan kualitas SDI perbankan syariah dan masalah kurangnya regulasi yang mendukung. Masalah lain yang berikutnya perlu mendapat perhatian adalah dari aspek pemerintah dan institusi lain, yaitu masalah kurangnya dukungan pemerintah dan institusi 
terkait yang menyeluruh. Alternatif pemecahan yang diusulkan adalah meningkatkan pemahaman dan kualitas SDI serta meninjau kembali regulasi yang dirasa memberatkan, seperti aturan kolektibilitas, dan membuat aturan-aturan yang bersifat memberikan insentif untuk meningkatkan penyaluran pembiayaan bagi hasil. Sementara itu, strategi kebijakan yang dianggap paling tepat untuk menyelesaikan masalah-masalah di perbankan syariah adalah dengan menerapkan directed market driven strategy, dimana aturan-aturan yang dibuat bersifat mengarahkan perbankan syariah agar berjalan pada rel syariah yang benar menuju arah perkembangan yang diinginkan.

8. Kurangnya pemahaman SDI perbankan syariah terutama disebabkan karena hampir semua SDI perbankan syariah berasal dari perbankan konvensional sehingga perilaku mereka cenderung seperti perilaku seorang conventional bankers, bukan Islamic bankers. Selain itu, rendahnya kualitas SDI perbankan syariah, selain karena mereka datang dari bank konvensional, pada umumnya mereka tidak diberi training yang memadai sebagai bekal mereka untuk dapat bekerja dengan baik sebagai Islamic bankers.

9. Dalam masalah kurangnya regulasi yang mendukung, salah satu contoh kebijakan yang paling banyak disoroti adalah masalah ketentuan tingkat peringatan kolektabilitas bagi skim pembiayaan mudharabah dan musyarakah yang tidak sama dan lebih ketat dibandingkan dengan skim-skim lain yang dirasa memberatkan bank.

10.Masalah rendahnya pembiayaan bagi hasil terbukti merupakan masalah yang multi dimensi yang mencakup berbagai pihak terkait, sehingga perlu adanya kesadaran bahwa masalah ini adalah masalah bersama yang memerlukan komitmen semua pihak terkait agar penyelesaian masalah dapat dilakukan secara komprehensif, sinergis, tuntas, dan berkesinambungan.

11.Antisipasi terhadap masalah-masalah pokok yang ditemukan perlu segera dilakukan agar perkembangan pesat perbankan syariah tetap mengarah sesuai dengan arah dan tujuan pengembangan perbankan syariah yang kita inginkan bersama.

12.Dari beberapa negara yang di survey, Sudan dapat dipergunakan sebagai contoh yang dapat dipedomani oleh kalangan perbankan dan regulator di Indonesia. Bank syariah yang sukses di Sudan memiliki SDI yang benar-benar paham tentang esensi bank syariah, sehingga cara berpikir dan cara kerja mereka benar-benar sebagai Islamic bankers. Pemahaman mengenai berbagai usaha yang dibiayai bank juga mereka kuasai benar, karena mereka pada umumnya mempunyai latar belakang usahawan sebelum bekerja di bank sehingga jiwa kewirausahaan ada pada mereka. Dalam ber-murabahah bank syariah di Sudan memiliki stok barang dalam gudangnya, yang berarti bahwa mereka menjalankan murabahah secara benar. Sementara itu, regulasi yang diterapkan oleh Bank of Sudan menggunakan strategi directed market driven. Dalam skim murabahah BOS hanya memberikan batasan indikatif, yang tidak 
mengikat, tentang maksimum porsi pembiayaan maksimum 30\% dengan margin maksimum $10 \%$. Selain itu, aturan kolektibilitas pembiayaan bagi hasil dibuat lebih longar dari pembiayaan murabahah. Kesemua aturan-aturan ini dirancang untuk lebih memberikan insentif dalam penyaluran pembiayaan bagi hasil.

\section{VI.2 Rekomendasi}

Berdasarkan hasil penelitian ini maka ada beberapa rekomendasi yang dapat diambil yaitu:

1. Masalah dominasi pembiayaan nonbagi hasil atau rendahnya pembiayaan bagi hasil harus dilihat secara proporsional oleh semua stakeholders, termasuk regulator dalam mengeluarkan kebijakan, dengan memperhatikan semua aspek yang terkait seperti aspek kesesuaian dengan prinsip syariah, tahapan pertumbuhan bank syariah, kemurnian operasinya (termasuk kemurnian akad-akad pembiayaannya), pembangunan SDI, dan sebagainya.

2. Peningkatan kualitas dan kuantitas SDI dapat dilakukan secara berjenjang, dimulai dengan jenjang jabatan yang paling atas, khususnya terkait dengan fit and proper test direktur utama yang berkesinambungan secara berkala. Fit and proper test bagi direktur perbankan harus dibedakan dengan fit and proper test bagi pimpinan bank konvensional. Dalam hal ini, tambahan "ghirah" yang dimiliki oleh calon pimpinan utama bank syariah seharusnya dijadikan persyaratan utama. Sehingga dengan "ghirah" yang tinggi ini komitmen yang diharapkan untuk menjalankan perbankan benar-benar sesuai dengan syariah dapat terwujud.

3. Peningkatan kualitas dan kuantitas SDI perbankan syariah dapat dilakukan dalam dua strategi, yaitu jangka pendek dan jangka panjang. Dalam jangka pendek, dari sisi internal perbankan perlu untuk meningkatkan training-training kepada pegawai pada semua level jabatan, termasuk level jabatan tertinggi. Disamping itu, spesialisasi AO (Account Officer) terhadap suatu bisnis juga perlu ditingkatkan. Dalam jangka panjang, pendidikan khusus mengenai ekonomi/perbankan Islam perlu untuk digalakkan, baik dalam bentuk lembaga tersendiri yang mengkhususkan pendidikan di bidang ekonomi dan perbankan Islam, maupun pendirian jurusan ekonomi dan perbankan Islam pada istitusi pendidikan umum. Dalam hal ini, peran aktif pemerintah (c.q. Departemen Pendidikan Nasional) dan swasta yang berkecimpung dalam dunia pendidikan sangat diharapkan.

4. Peningkatan kualitas dan kuantitas SDI perbankan syariah dari sisi bank sentral selaku regulator dapat dilakukan dengan memberikan batasan anggaran pendidikan minimum yang harus dikeluarkan oleh bank syariah. Selain itu pemerintah atau bank sentral dapat pula memberikan insentif dalam biaya pendidikan ini dengan cara, misalnya, setiap satu 
rupiah yang dikeluarkan oleh bank syariah, pemerintah atau bank sentral akan berpartisipasi sebesar satu rupiah juga, atau proporsi lain yang memungkinkan. Dapat juga bank sentral bertindak sebagai penyelenggara training, sedangkan pihak bank tinggal mengirim SDI-nya untuk ikut serta.

5. Kurangnya regulasi yang mendukung pembiayaan bagi hasil dapat disikapi dengan dua cara. Pertama, melihat kembali regulasi-regulasi yang sudah ada. Apabila terdapat regulasi yang dirasa memberatkan, menghambat, atau perlu penyempurnaan, maka perlu dilakukan revisi dan penyempurnaan. Kedua, dalam perancangan regulasi yang akan dikeluarkan, perlu selalu diupayakan agar dampaknya positif terhadap peningkatan pembiayaan bagi hasil.

6. Mengenai hal pertama, ketentuan mengenai tingkatan peringatan kolektibilitas untuk pembiayaan bagi hasil perlu ditinjau kembali agar tidak memberatkan bank. Regulasi di Sudan yang lebih memberikan kelonggaran tingkat kolektibilitas untuk pembiayaan bagi hasil dan dibarengi dengan seleksi nasabah yang ketat dapat dipakai sebagai contoh.

7. Mengenai hal kedua, pihak regulator dapat mencontoh apa yang dilakukan oleh Bank of Sudan dengan memberikan target indikatif porsi maksimum pembiayaan murabahah dan memberlakukan margin maksimum pembiayaan murabahah pada level tertentu. Regulator dapat juga memberikan target indikatif porsi minimum pembiayaan bagi hasil. Target-target indikatif ini dapat dibuat secara bertahap, misalnya porsi pembiayaan nonbagi hasil maksimum 80\% tahun 2006, 70\% tahun 2008, dan 60\% tahun 2010. Atau, porsi bagi hasil minimal mencapai 20\% tahun 2006, 30\% tahun 2008, dan 40\% tahun 2010 . Selain itu, sistem insentif dapat juga diterapkan untuk lebih memacu perbankan syariah meningkatkan porsi pembiayaan bagi hasilnya. Insentif ini bisa dalam bentuk kemudahankemudahan atau peningkatan tingkat kesehatan.

8. Purifikasi terhadap pelaksanaan praktek perbankan syariah merupakan agenda utama yang harus terus mendapat perhatian, kerana dengan adanya proses purifikasi ini perbankan syariah diarahkan untuk terus memperbaiki praktek-prakteknya untuk meningkatkan kemurniannya terhadap prinsip-prinsip syariah yang harus dipegang teguh (syaria compliance). Dengan meningkatnya kemurnian operasinya maka komposisi pembiayaan nonbagi hasil yang mendominasi akan terkurangi dengan sendirinya, dan pada akhirnya dapat menurunkan reputation risk.

9. Masalah kemurnian praktek murabahah perbankan syariah di Indonesia perlu segera mendapat perhatian. Penelitian mengenai masalah ini harus segera dilakukan agar penyelesaian masalah rendahnya pembiayaan bagi hasil dapat dilakukan dengan lebih komprehensif. Hal ini perlu dilakukan karena semua persoalan yang dibawa oleh lembaga yang memiliki label syariah dapat mendatangkan reputation risk karena label kesyariahannya itu. 
10.Dari sisi regulator, bahwa strategi directed market driven yang sebaiknya diterapkan. Perkembangan dan praktek perbankan syariah semestinya tidak sepenuhnya diserahkan kepada pasar, tetapi tidak juga secara ketat diatur oleh regulator, namun lebih kepada regulator yang memberikan arahan kemana perbankan syariah ini akan dikembangkan.

11. Masalah orientasi kualitas atau orientasi kuantitas juga merupakan hal yang perlu diarahkan oleh regulator. Perkembangan perbankan syariah secara kuantitas sangat diperlukan. Namun demikian, untuk menuju kepada perbankan syariah Indonesia menjadi the real islamic bank perlu juga melengkapi strategi pengembangan yang berorientasi kuantitas dengan strategi pengembangan yang berorientasi kualitas, agar perkembangan pesat perbankan syariah Indonesia tidak menuju ke arah yang tidak kita inginkan.

12.Kajian cost-benefit dan advantage-disadvantage mengenai posisi DSN diluar atau didalam bank sentral perlu dilakukan, untuk dapat dipakai sebagai bahan pertimbangan dalam mengefektifkan hubungan kerja DSN dan bank sentral. Selain itu, pemberdayaan fungsi DPS dengan membakukan wewenang, tanggung-jawab, dan hubungan kerja dengan pihak manajemen maupun DSN dan bank sentral perlu kiranya segera dilakukan. 


\section{Daftar Pustaka}

Afzal-ur-Rahman (1990), Economic Doctrines of Islam, Vol. 1-3, 3rd edition, Islamic Publication Ltd., Lahore, Pakistan.

Aggarwal, Rajesh K. and Yousef, Tarik (2000), "Islamic Banks and Investment Financing", Journal of Money, Credit, and Banking, Vol. 32, No. 1, February.

Ahmed, Ziauddin et.al. (1996), Money and Banking in Islam, International centre for Research in Islamic Economics, King Abdul Aziz University, Jeddah and Institute of Policy Studies, Islamabad.

Algaoud, Latifa M. and Lewis, Mervyn K. (2001), Perbankan Syariah, terjemahan, Serambi, Jakarta.

Al-Jarhi, Mabid Ali (2002), "Islamic Finance: An Efficient and Equitable Option", mimeo, The Islamic Research and Training Institute (IRTI).

Al-Omar, Fuad and Abdel-Haq, Mohammed (1996), Islamic Banking: Theory, Practice and Challenges, Oxford University Press, Karachi and Zed Books Ltd., New Jersey, USA.

Azis, Iwan J (2003), "Analytic Network Process with Feedback Influence: A New Approach to Impact Study, mimeo, paper presented in seminar organized by the Department of Urban and Regional Planning, University of lullinois, Urbana-Campaign.

Azis, Iwan J. (1990), "Analytic Hierarchy Process in the Benefit Cost Framework: A Post-evaluation of the Trans-Sumatra Highway Project", Europenan Journal of Operational Research, Vol. 48, No. 1, September 5, 1990.

Chapra, M. Umer (1985), Towards a Just Monetary System, Islamic Economics Series - 8, The Islamic Foundation, United Kingdom.

Chapra, M. Umer (2000), The Future of Economics: An Islamic Perspective, Islamic Economics Series - 21, The Islamic Foundation, United Kingdom.

Dar, Humayon A. and Presley, John R. (2000), "Lack of Profit Loss Sharing in Islamic Banking", International Journal of Islamic Financial Services, Vol. 2, No. 2, July-September.

Khan, M. Fahim (1995), Essays in Islamic Economics, Economics Series - 19, The Islamic Foundation, United Kingdom.

Khan, Tariqullah (1995), "Demand for and Supply of Mark-up and PLS Funds in Islamic Banking: Some Alternative Explanation", Islamic Economic Studies, IRTI, Vol. 3, No. 1, December. 
Muljawan, Dadang and Iljas, Nasirwan (2003), "Adverse Selection dan Implementasi Norma Islami Dalam Kegiatan Ekonomi",

Parinduri, Rasyad A. (2003), "Bank Islam Sebenar-benarnya", Koran Tempo, 11 Juli 2003.

Saaty, Thomas L. (1996), "Fundamentals of Decision Making and Priority Theory with The Analytic Hierarchy Process", RWS Publication, Pittsburgh.

Saaty, Thomas L. (1999), "Fundamentals of The Analytic Network Process", paper presented in ISAHP 1999, Kobe, Japan, August 12-14.

Saaty, Thomas L. (2001), "Decision Making with Dependence and Feedback: The Analytic Network Process", RWS Publication, Pittsburgh.

Saaty, Thomas L. (2003), "The Seven Pillars of the Analytic Hierarchy Process", mimeo.

Saeed, Abdullah (1999), Islamic Banking and Interest: A study of the Prohibition of Riba and its Contemporary Interpretation, EJ Brill, Leiden.

Samad, Abdus and Hassan, M.Kabir (1999), "The Performance of Malaysian Islamic Bank During 1987-1997: An Explanatory Study", International Journal of Islamic Finance Services, Vol. 1, No. 3, October-December.

Sarker, M. Abdul Awwal (1999), "Islamic Business Contracts, Agency Problem and the Theory of the Islamic Firm", International Journal of Islamic Finance Services, Vol. 1, No. 2, JulySeptember.

Siregar, Mulya E. and llyas, Nasirwan (2002), "Penempatan Aktiva Produktif Bank Syariah", Jurnal Ekonomi Syariah MUAMALAH, Vol. 1, No. 1, Agustus. 